\title{
Sea surface temperature variability and sea-ice extent in the subarctic northwest Pacific during the past 15,000 years
}

\author{
Lars Max, ${ }^{1}$ Jan-Rainer Riethdorf, ${ }^{2}$ Ralf Tiedemann, ${ }^{1}$ Maria Smirnova, ${ }^{3}$ \\ Lester Lembke-Jene, ${ }^{1}$ Kirsten Fahl, ${ }^{1}$ Dirk Nürnberg, ${ }^{2}$ Alexander Matul, ${ }^{3}$ \\ and Gesine Mollenhauer ${ }^{1}$ \\ Received 27 January 2012; revised 2 July 2012; accepted 3 July 2012; published 16 August 2012.
}

[1] Past changes in North Pacific sea surface temperatures and sea-ice conditions are proposed to play a crucial role in deglacial climate development and ocean circulation but are less well known than from the North Atlantic. Here, we present new alkenone-based sea surface temperature records from the subarctic northwest Pacific and its marginal seas (Bering Sea and Sea of Okhotsk) for the time interval of the last $15 \mathrm{kyr}$, indicating millennial-scale sea surface temperature fluctuations similar to short-term deglacial climate oscillations known from Greenland ice core records. Past changes in sea-ice distribution are derived from relative percentage of specific diatom groups and qualitative assessment of the $\mathrm{IP}_{25}$ biomarker related to sea-ice diatoms. The deglacial variability in sea-ice extent matches the sea surface temperature fluctuations. These fluctuations suggest a linkage to deglacial variations in Atlantic meridional overturning circulation and a close atmospheric coupling between the North Pacific and North Atlantic. During the Holocene the subarctic North Pacific is marked by complex sea surface temperature trends, which do not support the hypothesis of a Holocene seesaw in temperature development between the North Atlantic and the North Pacific.

Citation: Max, L., J.-R. Riethdorf, R. Tiedemann, M. Smirnova, L. Lembke-Jene, K. Fahl, D. Nürnberg, A. Matul, and G. Mollenhauer (2012), Sea surface temperature variability and sea-ice extent in the subarctic northwest Pacific during the past 15,000 years, Paleoceanography, 27, PA3213, doi:10.1029/2012PA002292.

\section{Introduction}

[2] Knowledge of the deglacial SST development and variability in sea-ice extent in the subarctic Pacific provide important climate boundary conditions to understand oceanic/atmospheric teleconnections between the Atlantic and the Pacific and to evaluate most recent hypotheses related to deep water formation in the North Pacific (NPacific). However, the sea surface temperature (SST) variability in the subarctic N-Pacific realm as well as the timing of SST changes during the last glacial termination and the Holocene have remained elusive. In general, the spatial and temporal development of SSTs in the N-Pacific on centennialmillennial timescales is only poorly conceived for several reasons: (1) SST reconstructions from the N-Pacific are sparse (Figure 1); (2) available SST reconstructions are based on a variety of different temperature proxies, which in turn may lead to inconsistent temperature signals since the

\footnotetext{
${ }^{1}$ Alfred Wegener Institute for Polar and Marine Research, Bremerhaven, Germany.

${ }^{2}$ GEOMAR, Helmholtz-Zentrum für Ozeanforschung Kiel, Kiel, Germany.

${ }^{3}$ P. P. Shirshov Institute of Oceanology, Moscow, Russia.

Corresponding author: L. Max, Alfred Wegener Institute for Polar and Marine Research, Am Handelshafen 12, DE-27570 Bremerhaven, Germany. (lars.max@awi.de)

C2012. American Geophysical Union. All Rights Reserved. 0883-8305/12/2012PA002292
}

recording of each proxy can be afflicted with a seasonal bias and/or is related to a different water depth; (3) the availability of carbonate-bearing sediment records with high sedimentation rates is restricted to shallow water depths due to the shallow position of the calcite compensation depth in the N-Pacific $(<3000 \mathrm{~m})$; (4) the absence of carbonate for major parts of N-Pacific sediments excludes the application of carbonate-based proxies and ${ }^{14} \mathrm{C}$-datings on planktonic foraminifers, thus limiting detailed climate reconstructions; and (5) changes in paleo- ${ }^{14} \mathrm{C}$ reservoir ages are not well defined and may lead to imprecise age models in the N-Pacific [Sarnthein et al., 2004].

[3] As a consequence, model simulations and proxy-based interpretations have partially led to contradictory results concerning the SST variability in the N-Pacific and its underlying mechanisms during the last deglaciation. Studies with general circulation models (GCMs) suggest both an inphase behavior of deglacial SST variability between the North Atlantic (N-Atlantic) and the N-Pacific [Mikolajewicz et al., 1997; Vellinga and Wood, 2002; Okumura et al., 2009; Chikamoto et al., 2012] as well as an out-of-phase response [Saenko et al., 2004; Schmittner et al., 2007; Okazaki et al., 2010]. The in-phase behavior has been related to rapid atmospheric teleconnections, acting on years to decades. The out-of-phase response has been attributed to oceanic readjustments of the Atlantic meridional overturning circulation (AMOC). More specifically, the simulated 

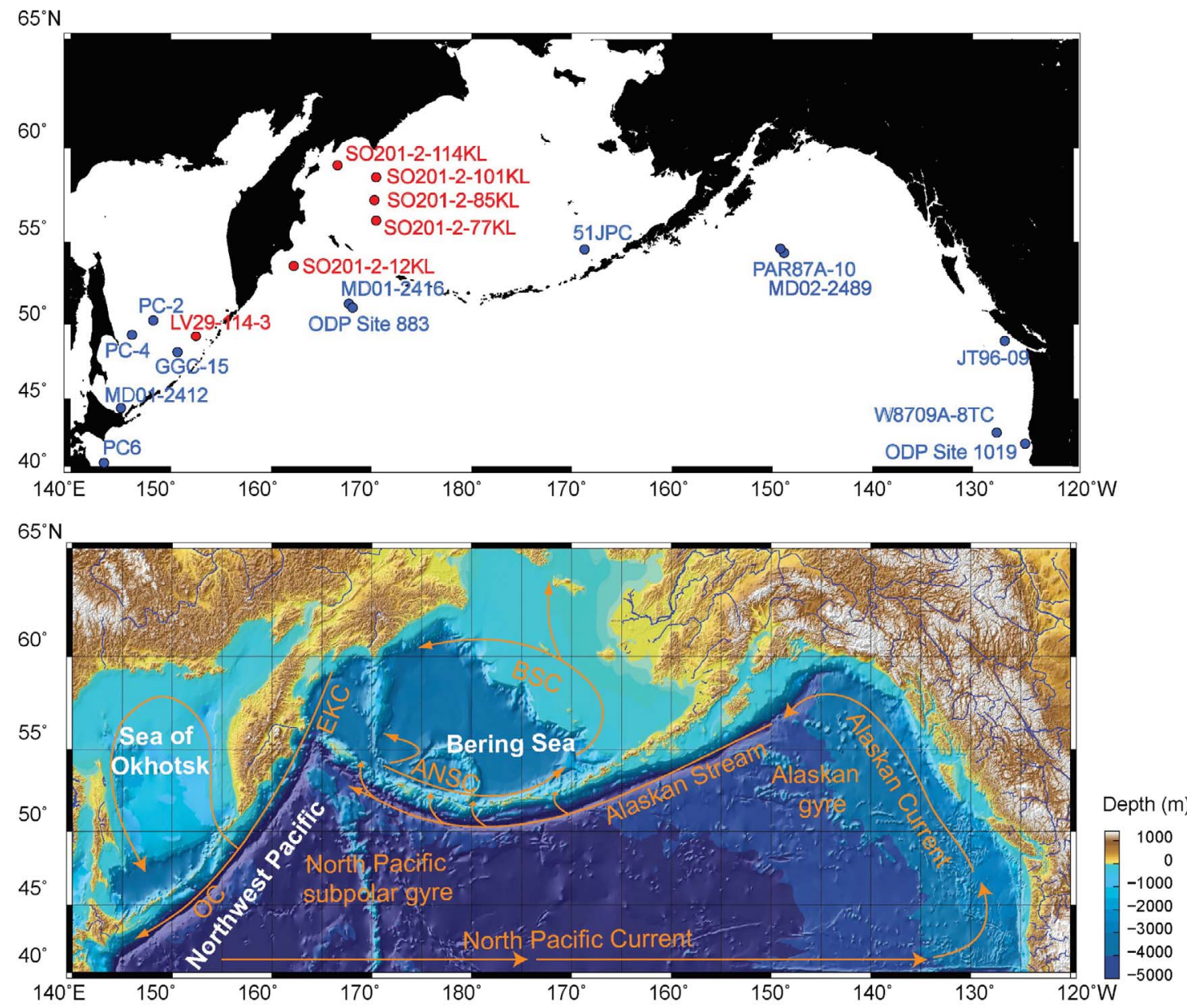

Figure 1. (top) Core sites in the subarctic Pacific from this study (in red), together with published sediment records (in blue) in the Sea of Okhotsk (PC-2 and PC-4 [Seki et al., 2004a], GGC-15 [Ternois et al., 2000], MD01-2412 [Harada et al., 2006b]) the Bering Sea (51JPC [Caissie et al., 2010]) and the N-Pacific (PC6 [Minoshima et al., 2007], ODP Site 883 [Kiefer et al., 2001], MD012416 [Sarnthein et al., 2004], PAR87A-10 [Pisias et al., 2001], MD02-2489 [Gebhardt et al., 2008], JT96-09 [Kienast and McKay, 2001], W8709A-8TC [Pisias et al., 2001], ODP Site 1019 [Barron et al., 2003]). (bottom) Bathymetric chart of the subarctic N-Pacific with the general surface circulation pattern indicated by orange arrows (modified after Stabeno et al. [1999]). OC = Oyashio Current; EKC = East Kamchatka Current; ANSC = Aleutian North Slope Current; BSC = Bering Slope Current.

reduction of the AMOC as a consequence of enhanced sea surface freshening in the N-Atlantic (as during Heinrich 1 and the Younger Dryas) resulted in a strengthening of the Pacific meridional overturning circulation (PMOC) and an associated warming in the N-Pacific. The warming resulted from an enhanced poleward heat transport from the subtropics to the N-Pacific. Accordingly, the proposed seesaw between AMOC reduction and PMOC intensification suggests a N-Pacific warming during Heinrich 1 (H1) and the Younger Dryas (YD). In turn, the reestablishment of the AMOC (shutdown of PMOC) led to a surface cooling in the N-Pacific during the Bølling/Allerød $(\mathrm{B} / \mathrm{A})$ and the early Holocene. Consequently, the interplay between the two meridional overturning cells is expected to provide millennial-scale out-of-phase fluctuations in SST between the N-Atlantic and the N-Pacific [e.g., Saenko et al., 2004].

[4] The few available deglacial SST proxy records from the N-Pacific and its adjacent seas also provide a quite inconsistent picture. The records support both an in-phase and out-of-phase relationship with regard to the N-Atlantic SST development or show continuously cold SSTs from the last glacial to the onset of the Holocene (no warming event during the B/A). For example, a remarkable similarity between the Greenland/N-Atlantic temperature evolution and SST records, based on alkenone paleothermometry, radiolarian assemblages and dinocyst studies, was derived from sediment records of the subarctic northeast Pacific (NE-Pacific) [Kienast and McKay, 2001; Pisias et al., 2001; Seki et al., 2002; Barron et al., 2003], the Bering Sea [Caissie et al., 2010] and the Sea of Okhotsk [Ternois et al., 2000]. These records rather argue for an in-phase relationship of temperature fluctuations between the N-Pacific and N-Atlantic. On the other hand, N-Pacific SST records from pelagic core MD01-2416 and MD02-2489, derived from planktonic $\mathrm{Mg} / \mathrm{Ca}$ ratios and from census counts of planktonic foraminifera using the SIMMAX transfer function, 
indicate a different SST development. These records suggest temperature maxima during $\mathrm{H} 1$ and the YD and thus millennial-scale fluctuations out-of-phase with the Greenland/ N-Atlantic temperature evolution [Sarnthein et al., 2004; Kiefer and Kienast, 2005; Sarnthein et al., 2006; Gebhardt et al., 2008]. The timing of these temperature changes is possibly best constrained in sediment record MD01-2416 from the pelagic NW-Pacific. Unfortunately, this record does not allow a direct comparison between $\mathrm{Mg} / \mathrm{Ca}$ - and alkenone-derived SSTs. Other records provide inconsistent trends of deglacial SST variability. For example, some records derived from the Sea of Okhotsk and the Pacific continental margin of Japan show no SST maximum during the $\mathrm{B} / \mathrm{A}$, and the deglacial temperature rise does not appear before the end of the YD [Seki et al., 2004a; Minoshima et al., 2007].

[5] For the Holocene, Kim et al. [2004] summarized alkenone-based SST reconstructions from the N-Pacific and the $\mathrm{N}$-Atlantic using a coupled atmosphere-ocean general circulation model to assess the inter-oceanic teleconnected climate variability. Their investigations led to the hypothesis of a long-term temperature seesaw between the N-Atlantic and the N-Pacific. The model-supported proxy-study suggests a warming trend in the N-Pacific and a cooling trend in the $\mathrm{N}$-Atlantic for the time period of the last 7 kyr. The inverse SST trends between the N-Atlantic and the N-Pacific have been attributed to an atmospheric interaction of the positive Pacific North American (PNA) pattern and the negative North Atlantic Oscillation (NAO) phase. However, the derived warming trend in the N-Pacific relies on a single proxy record from the NW-Pacific only [Ternois et al., 2000], which is marked by low alkenone concentrations (close to the detection limit) within the time interval spanning the last $8 \mathrm{kyr}$ BP.

[6] Irrespective of the differences in Holocene and deglacial Pacific SST variability, an exact chronostratigraphic correlation between Greenland ice core records and ${ }^{14} \mathrm{C}$-dated deglacial marine climate records is limited by assumptions about the ${ }^{14} \mathrm{C}$ reservoir age of the surface water, the habitat in which planktonic foraminifera incorporate the ${ }^{14} \mathrm{C}$ signal into their carbonate shells. Knowledge of the ${ }^{14} \mathrm{C}$ reservoir age is a necessary precondition for converting radiocarbon ages into calendar years in order to balance for the ${ }^{14} \mathrm{C}$ disequilibrium between the upper ocean and the atmosphere. Since the variability of past reservoir ages is largely unknown, most studies assume a constant reservoir effect over time, thereby taking an uncertainty of several hundred years into account. Such uncertainties may increase to more than thousand years within time intervals associated with prominent atmospheric ${ }^{14} \mathrm{C}$-plateaus (i.e., intervals of very low ${ }^{14} \mathrm{C}$ change with calendar age). Such plateaus especially mark the period of the last deglaciation. Accordingly, the lead and lag of different proxies, indicative of rapid climate change in the subarctic Pacific, are difficult to constrain in comparison to the Greenland climate signal.

[7] Here, we present the first alkenone-derived highresolution SST estimates from the subarctic NW-Pacific continental margin and the western Bering Sea as well as a new record from the southeastern Sea of Okhotsk. Our study provides a stratigraphic framework for the NW-Pacific realm, which is based on detailed core-to-core correlations and $37 \mathrm{AMS}{ }^{14} \mathrm{C}$ datings. This framework is well constrained between 20 to $\sim 6 \mathrm{ka} \mathrm{BP}$ and can be used via X-ray Fluorescence (XRF) core scanner data (e.g., Ca intensities) to transfer ages to other available and future sediment records. The relatively high sedimentation rates enable us to investigate past SST changes on multicentennial to millennial timescales in comparison to rapid climate oscillations known from other parts of the N-Pacific and the N-Atlantic for the last 15 kyr. Additionally, relative percentages of specific diatom groups in combination with qualitative measurements of the $\mathrm{C}_{25}$ monounsaturated hydrocarbon $\left(\mathrm{IP}_{25}\right)$ are used to assess past changes in the sea-ice extent [Belt et al., 2007; Müller et al., 2009] with regard to short-term warm/cold fluctuations. Our data suggest that the subarctic NW-Pacific region is characterized by deglacial SST fluctuations, which show strong similarities to the Greenland/N-Atlantic SST evolution. The sea-ice distribution is closely coupled to the SST variability. The SST records from the NW-Pacific realm presented here provide new insights into the spatiotemporal pattern of millennial-scale SST variability during the deglacial period and the Holocene, which in turn will aid to further constrain the impact of past rapid climate oscillations on N-Pacific oceanography. Our results shed new light onto the discussion of whether the deglacial temperature development in the NW-Pacific supports an in-phase or an out-of-phase behavior with respect to the N-Atlantic SST development and the related seesaw between AMOC and PMOC. With respect to the Holocene, the SST reconstructions are also used to reconsider the hypothesis of a seesaw mechanism that has been proposed to have led to contrasting long-term temperature trends between the $\mathrm{N}$-Atlantic and the N-Pacific (temperature seesaw) during the past $7 \mathrm{kyr}$.

\section{Regional Setting}

[8] The subarctic Pacific regions are characterized by a large, seasonal variability in SST and sea-ice distribution, tightly coupled to atmospheric pressure cells which in turn are influenced by large-scale interannual-decadal variability associated with the Pacific-North American (PNA) pattern and the Pacific Decadal Oscillation (PDO) [Niebauer, 1988; Mantua et al., 1997; Niebauer, 1998; Overland et al., 2002]. During winter, the contrast between the Siberian High and Aleutian Low-Pressure System (ALPS) brings cold air masses from the Arctic to the subarctic Pacific, which results in strong sea surface cooling and mixing of nutrient-rich subsurface waters and favors the expansion of sea-ice in the Bering Sea and Sea of Okhotsk. During summer, both increased insolation and weakening of the ALPS lead to warm SSTs, ice-free conditions and strong upper-ocean stratification [Ohtani et al., 1972]. This leads to strong, seasonal temperature differences between winter $\left(0-2^{\circ} \mathrm{C}\right)$ and summer $\left(8-10^{\circ} \mathrm{C}\right)$ SSTs in the subarctic NW-Pacific and its marginal seas. Maxima in biogenic productivity occur during spring (dominated by diatoms) and late summer (dominated by coccolithophorids).

[9] The structure of the upper water column is characterized by the presence of a strong halocline, which is a permanent feature of the subarctic Pacific. It forms a barrier for the heat and gas exchange between the deep ocean and the atmosphere as well as for the supply of nutrients into the photic zone. It leads to the highest carbon export efficiency 
Table 1. Core Locations in the Subarctic NW-Pacific, Sea of Okhotsk and Western Bering Sea as Well as the Performed Proxy Studies

\begin{tabular}{|c|c|c|c|c|c|}
\hline Sediment Core & Latitude $\left({ }^{\circ} \mathrm{N}\right)$ & Longitude $\left({ }^{\circ} \mathrm{E}\right)$ & Depth (mbsl) & Study Area & Performed Proxy Studies ${ }^{a}$ \\
\hline LV29-114-3 & $49^{\circ} 22.54^{\prime}$ & $152^{\circ} 53.23^{\prime}$ & 1765 & Sea of Okhotsk & $\mathrm{U}_{37}^{\mathrm{K}^{\prime}}, \mathrm{IP}_{25}, \mathrm{CaCO}_{3}, \mathrm{CL},{ }^{14} \mathrm{C}$ \\
\hline SO201-2-12KL & $53^{\circ} 59.47^{\prime}$ & $162^{\circ} 22.51^{\prime}$ & 2145 & NW-Pacific & $\mathrm{U}_{37}^{\mathrm{K}}, \mathrm{IP}_{25}$, Opal, DS, CL, ${ }^{14} \mathrm{C}$ \\
\hline SO201-2-77KL & $56^{\circ} 19.83^{\prime}$ & $170^{\circ} 41.98^{\prime}$ & 2135 & western Bering Sea & $\mathrm{U}_{37}^{\mathrm{K}}, \mathrm{IP}_{25}, \mathrm{CL},{ }^{14} \mathrm{C}$ \\
\hline SO201-2-85KL & $57^{\circ} 30.30^{\prime}$ & $170^{\circ} 24.77^{\prime}$ & 968 & western Bering Sea & $\mathrm{U}_{37}^{\mathrm{K}}, \mathrm{IP}_{25}, \mathrm{CL},{ }^{14} \mathrm{C}$ \\
\hline SO201-2-101KL & $58^{\circ} 52.52^{\prime}$ & $170^{\circ} 41.45^{\prime}$ & 630 & western Bering Sea & $\mathrm{U}_{37}^{\mathrm{K}^{\prime}}, \mathrm{IP}_{25}, \mathrm{CL},{ }^{14} \mathrm{C}$ \\
\hline SO201-2-114KL & $59^{\circ} 13.87^{\prime}$ & $166^{\circ} 59.32^{\prime}$ & 1376 & western Bering Sea & $\mathrm{U}_{37}^{\mathrm{K}}, \mathrm{IP}_{25}, \mathrm{CL},{ }^{14} \mathrm{C}$ \\
\hline
\end{tabular}

${ }^{\mathrm{a}} \mathrm{U}_{37}^{\mathrm{K}^{\prime}}$ : alkenone paleothermometry; $\mathrm{IP}_{25}$ : sea-ice diatoms biomarker; Opal: wt.\% biogenic opal; $\mathrm{CaCO}_{3}:$ wt. $\% \mathrm{CaCO}_{3}$; CL: Core logging; ${ }^{14} \mathrm{C}: \mathrm{AMS}{ }^{14} \mathrm{C}$ datings; DS: Diatom studies.

in the world oceans and acts as a net sink of atmospheric $\mathrm{CO}_{2}$ today [Honda et al., 2002].

[10] The surface circulation of the subarctic NW-Pacific follows a large-scale cyclonic pattern of surface currents, which regulate the exchange of heat and nutrients between different ocean regions. The dominant large-scale circulation pattern in the subpolar N-Pacific consists of the KuroshioNorth Pacific Current system in the South and two counterclockwise circulating systems: the Alaskan gyre in the East and the western North Pacific subpolar gyre (Figure 1). The North Pacific Current (the Kuroshio extension) transports relatively warm water masses eastward into the Alaskan gyre. The Alaskan Stream forms the northern boundary current and transports water masses from the Alaskan gyre along the Aleutian Islands into the western subpolar gyre, thereby entering the Bering Sea through several passages between the Aleutian Islands. This inflow drives a largescale counterclockwise surface circulation in the Bering Sea. The surface waters leave the Bering Sea via the Bering Strait into the Arctic Ocean but mainly through the Kamchatka Strait back into the N-Pacific via the East Kamchatka Current (EKC). The EKC delivers nutrient-rich waters from the Bering Sea into the NW-Pacific [Stabeno et al., 1999] and represents the western branch of the North Pacific subpolar gyre. On its path to the South, a part of the EKC enters the Sea of Okhotsk through the Kurile Island Arc, thereby influencing the water mass signature of the Okhotsk gyre. During winter, the intrusion of the relatively warm EKC promotes ice-free conditions around the southern tip of Kamchatka [Seki et al., 2004b] (Figure 1).

\section{Material and Methods}

[11] We investigated six piston cores from the western Bering Sea, the continental slope of east Kamchatka and the southeastern Sea of Okhotsk (Figure 1). Sediment records were obtained during cruises LV29 KOMEX Leg 2 with R/V Akademik Lavrentyev in 2002 and R/V Sonne during SO201 KALMAR Leg 2 in 2009. Core site selection was done by intensive sediment echo-sounding studies onboard to detect high-resolution sediment deposits, which are located well above the shallow calcite compensation depth (CCD). Our sediment records provide sufficient amounts of carbonate-bearing material for detailed paleoceanographic reconstructions (Table 1) except the younger part of the Holocene. During the last $6 \mathrm{kyr}$, the productivity of calcareous plankton was generally low in the NW-Pacific and the productivity dominated by siliceous diatoms. The high amounts of silicious diatom tests further diluted the quantity of planktonic carbonate shells within the sediments [Gorbarenko et al., 2002].

\subsection{Stratigraphic Approach}

\subsubsection{AMS- ${ }^{14} \mathrm{C}$-Dating}

[12] AMS ${ }^{14} \mathrm{C}$-ages were measured on monospecific samples of the planktonic foraminifera Neogloboquadrina pachyderma sinistral (N. pachyderma sin.) from 125-250 $\mu \mathrm{m}$ fraction. The radiocarbon dating has been performed by the National Ocean Science Accelerator Mass Spectrometry Facility (NOSAMS) at Woods Hole Oceanographic Institute (WHOI) and Leibniz-Laboratory for Radiometric Dating and Isotope Research at Kiel University. Radiocarbon ages have been reported according to the convention outlined by Stuiver and Polach [1977] and Stuiver [1980]. All radiocarbon ages were converted into calibrated 1-sigma calendar age ranges using the calibration tool Calib Rev 6.0 [Stuiver and Reimer, 1993] with the Intcal09 atmospheric calibration curve [Reimer et al., 2009] and considering a constant reservoir age throughout the time period covered by the sediment records (Table 2).

\subsubsection{Biogenic Opal and $\mathrm{CaCO}_{3}$}

[13] Biogenic opal and $\mathrm{CaCO}_{3}$ were measured at GEOMAR, Kiel. Biogenic opal concentrations were determined from bulk sediment, using the automated leaching method according to Müller and Schneider [1993] by molybdateblue spectrophotometry. Results are given with respect to the mineral correction of DeMaster [1981].

[14] Total carbon contents (TC) were determined with a CARLO ERBA Model NA 1500 CNS analyzer. TC was measured on bulk sediments and total organic carbon was derived from decalcified samples. The inorganic carbon $\left(\mathrm{CaCO}_{3}\right)$ content was calculated by the difference between $\mathrm{TC}$ and TOC as follows:

$$
\mathrm{CaCO}_{3}=(\mathrm{TC}-\mathrm{TOC}) \times 8.333
$$

\subsubsection{Core Logging Data}

[15] Relative sedimentary elemental composition was measured using the Avaatech X-ray Fluorescence (XRF) core scanner at the Alfred Wegener Institute for Polar and Marine Research, Bremerhaven. Each core segment was triple-scanned for element analysis at $1 \mathrm{~mA}$ and tube voltages of $10 \mathrm{kV}(\mathrm{Al}, \mathrm{Si}, \mathrm{S}, \mathrm{K}, \mathrm{Ca}, \mathrm{Ti}, \mathrm{Fe}), 30 \mathrm{kV}(\mathrm{Cu}, \mathrm{Zn}, \mathrm{Br}$, $\mathrm{Rb}, \mathrm{Zr}, \mathrm{Sr}, \mathrm{Mo}$ ) and $50 \mathrm{kV}$ (Ag, Cd, Sn, Te, Ba), using a sampling resolution of $1 \mathrm{~cm}$ and $30 \mathrm{~s}$ count time.

[16] Color and light reflectance properties of the sediment cores have been measured with a Minolta CM 508d handheld spectrophotometer directly after core splitting onboard [Dullo et al., 2009]. Measurements were conducted at $1 \mathrm{~cm}$ interval. Reflectance data was converted into $\mathrm{L}^{*}, \mathrm{a}^{*}$ and $\mathrm{b}^{*}$ color space with the software Spectramagic. 
Table 2. AMS ${ }^{14} \mathrm{C}$ Ages of the Sediment Records With Calibrated Calendar Age $\pm 1 \sigma$ (Years) and Applied Reservoir Age Correction Used in This Study

\begin{tabular}{|c|c|c|c|c|c|}
\hline Laboratory Number & Sediment Core & $\begin{array}{l}\text { Core Depth } \\
\quad(\mathrm{cm})\end{array}$ & $\begin{array}{l}\text { Radiocarbon Age } \\
\text { (years) }\end{array}$ & $\begin{array}{c}\text { Calendar Age } \pm 1 \sigma \\
\text { (years) }\end{array}$ & $\begin{array}{l}\text { Reservoir Age } \\
\text { (years) }\end{array}$ \\
\hline Transferred age & LV29-114-3 & 108 & $5850 \pm 60^{\mathrm{a}}$ & $5607-5730$ & 900 \\
\hline OS-88042 & & 162 & $8320 \pm 40$ & $8236-8310$ & 900 \\
\hline KIA30864 & & 197 & $9630 \pm 50$ & $9764-10067$ & 900 \\
\hline KIA30863 & & 232 & $10465 \pm 50$ & $10808-11080$ & 900 \\
\hline KIA30867 & & 272 & $12290 \pm 55$ & 13164-13308 & 900 \\
\hline KIA30865 & & 292 & $13180 \pm 60$ & $13960-14457$ & 900 \\
\hline KIA30868 & & 317 & $14400 \pm 80$ & $16538-16827$ & 900 \\
\hline KIA30866 & & 352 & $15130 \pm 80$ & $17117-17497$ & 900 \\
\hline OS-85655 & SO201-2-12KL & 210 & $9390 \pm 40$ & $9484-9527$ & 900 \\
\hline KIA44680 & & 295 & $10570 \pm 50$ & $11080-11191$ & 900 \\
\hline OS-87895 & & 340 & $10800 \pm 65$ & $11231-11368$ & 900 \\
\hline OS-92047 & & 508 & $12500 \pm 50$ & $13340-13498$ & 900 \\
\hline OS-87891 & & 550 & $12900 \pm 50$ & $13782-13918$ & 900 \\
\hline OS-87902 & & 610 & $13350 \pm 65$ & $14219-14752$ & 900 \\
\hline OS-92150 & & 695 & $13900 \pm 55$ & $15227-15872$ & 900 \\
\hline KIA44682 & & 820 & $16160 \pm 80$ & $18491-18666$ & 900 \\
\hline KIA44683 & & 875 & $17090 \pm 90$ & 19254-19457 & 900 \\
\hline OS-85671 & SO201-2-77KL & 105 & $9570 \pm 45^{\mathrm{b}}$ & $10051-10152$ & 700 \\
\hline OS-85658 & & 115 & $10450 \pm 40^{\mathrm{c}}$ & $11174-11222$ & 700 \\
\hline OS-90700 & & 155 & $11500 \pm 50$ & $12608-12727$ & 700 \\
\hline OS-85657 & & $167-170$ & $12750 \pm 50$ & $13823-13967$ & 700 \\
\hline OS-85664 & & 180 & $13200 \pm 45$ & $14501-14945$ & 700 \\
\hline OS-85665 & SO201-2-85KL & 26 & $9950 \pm 40^{\mathrm{b}}$ & $10378-10507$ & 700 \\
\hline KIA42231 & & 45 & $10315 \pm 65^{\mathrm{c}}$ & 10791-10966 & 700 \\
\hline OS-85669 & & 60 & $11950 \pm 45$ & 13104-13217 & 700 \\
\hline KIA42232 & & 70 & $12620 \pm 90$ & $13665-13887$ & 700 \\
\hline OS-87896 & & 95 & $13850 \pm 55$ & $15803-15822$ & 700 \\
\hline OS-87890 & & 135 & $17350 \pm 65$ & 19575-19895 & 700 \\
\hline KIA42233 & & 155 & $20720 \pm 160$ & 23706-24194 & 700 \\
\hline OS-87887 & SO201-2-101KL & 10 & $12600 \pm 55$ & $13686-13838$ & 700 \\
\hline OS-88041 & & 90 & $14950 \pm 60$ & $17165-17506$ & 700 \\
\hline KIA42229 & & 110 & $17310 \pm 120$ & 19541-19919 & 700 \\
\hline Transferred age & & 140 & $20720 \pm 160^{\mathrm{d}}$ & $23706-24194$ & 700 \\
\hline KIA42230 & & 190 & $22510 \pm 190$ & $25876-26351$ & 700 \\
\hline KIA42506 & & 260 & $29270 \pm 440$ & $32121-33539$ & 700 \\
\hline KIA42235 & SO201-2-114KL & 39 & $10200 \pm 70$ & $10600-10805$ & 700 \\
\hline KIA42236 & & $76-78$ & $10645 \pm 50$ & 11249-11404 & 700 \\
\hline KIA42237 & & 114 & $12160 \pm 80$ & $13249-13403$ & 700 \\
\hline KIA42238 & & 153 & $13410 \pm 100$ & $14727-15237$ & 700 \\
\hline
\end{tabular}

${ }^{\mathrm{a}}$ The ${ }^{14} \mathrm{C}$ age transferred from sediment core V34-98 [Gorbarenko et al., 2002].

${ }^{\mathrm{b}}$ The ${ }^{14} \mathrm{C}$ ages used to define the carbonate spike 1.

${ }^{\mathrm{c}}$ The ${ }^{14} \mathrm{C}$ ages used to define the carbonate spike 2 .

${ }^{\mathrm{d}}$ The ${ }^{14} \mathrm{C}$ age transferred from sediment core SO201-2-85KL.

\subsection{Alkenone Analysis and Sea Surface Temperatures $\left(\mathbf{U}_{37}^{\mathrm{K}^{\prime}}\right)$}

[17] Discrete samples (5-10 g) were taken from bulk sediment, freeze-dried and stored frozen until further analysis. Samples were extracted with an accelerated solvent extractor (ASE-200, Dionex) at $100^{\circ} \mathrm{C}$ and 1000 psi for 15 min by using dichlormethane (DCM) as a solvent. Remaining extracts were separated by silica gel column chromatography into three sub-fractions with the following mixture of solvents: fraction $1,5 \mathrm{ml}$ hexane; fraction 2 , a mixture of $5 \mathrm{ml}$ DCM $\backslash$ hexane (1:1); fraction 3, $5 \mathrm{ml} \mathrm{DCM}$. Alkenones were eluted in the third fraction and prepared in $100 \mu \mathrm{l}$ hexane. The third fraction was measured at the Alfred Wegener Institute for Polar and Marine Research (AWI) by using a HP 6890 gas chromatograph, equipped with a cold injection system, a DB-1MS fused silica capillary column $(60 \times 0.32 \mathrm{~mm}$ inner diameter, film thickness of $0.25 \mu \mathrm{m})$ and a flame ionization detector. Individual alkenone (C37:3, $\mathrm{C} 37: 2)$ identification was based on the retention time and the comparison with an external standard, which were also used for controlling the instrument stability. The detection threshold for the alkenones is almost $10 \mathrm{ng} / \mathrm{g}$. The alkenone unsaturation index $\left(\mathrm{U}_{37}^{\mathrm{K}^{\prime}}\right)$ as proxy for SST [Brassell et al., 1986; Prahl and Wakeham, 1987] was calculated following the relationship between $\mathrm{U}_{37}^{\mathrm{K}^{\prime}}$ and temperature as proposed by Müller et al. [1998], which is based on a global core top calibration $\left(60^{\circ} \mathrm{N}-60^{\circ} \mathrm{S}\right)$ :

$$
\mathrm{U}_{37}^{\mathrm{K}^{\prime}}=0.033 \mathrm{~T}\left({ }^{\circ} \mathrm{C}\right)+0.044 \text {. }
$$

[18] The standard error of this calibration is reported as $+/-0.050 \mathrm{U}_{37}^{\mathrm{K}^{\prime}}$-units or $+/-1.5^{\circ} \mathrm{C}$. However, it has to be mentioned that for the lower end of the used temperature calibration a larger error is reported but still keeps its significance in conjunction to other results from this study. It is also known that in the subpolar N-Pacific, alkenone producers are limited to specific seasons and represent more likely the late summer/early fall SST [Harada et al., 2003, 2006a; Seki et al., 2007]. Nevertheless, for a direct comparison to other studies, we decided to use the calibration 
after Müller et al. [1998] mentioned above, which is widely used in the N-Pacific and other regions rather than the polar temperature function of the Southern Ocean as proposed by Sikes et al. [1997].

\subsection{Qualitative Assessment of Sea-Ice Distribution $\left(\mathbf{I P}_{25}\right)$ and Microfossil Studies (Diatoms)}

[19] Recently it has been recognized that when detected in marine sediments, the $\mathrm{C}_{25}$ isoprenoid lipid $\left(\mathrm{IP}_{25}\right)$ biosynthesized by Arctic sea-ice diatoms acts as a proxy for previous spring sea-ice occurrence and subsequent melt [Belt et al., 2007]. We performed qualitative $\mathrm{IP}_{25}$ analysis on selected samples, based on significant changes in our proxy records and reflecting different climate intervals according to our age model. For this purpose the hydrocarbon fraction (fraction 1, see above) of selected samples were measured with an Agilent 6850 GC (30 m HP-5MS column, $0.25 \mathrm{~mm}$ i.d., $0.25 \mu \mathrm{m}$ film thickness) coupled to an Agilent $5975 \mathrm{C}$ VL mass selective detector. The GC oven was heated from $60^{\circ} \mathrm{C}$ to $150^{\circ} \mathrm{C}$ at $15^{\circ} \mathrm{C} \mathrm{min}{ }^{-1}$, and then at $10^{\circ} \mathrm{C} \mathrm{min}^{-1}$ to $320^{\circ} \mathrm{C}$ (held $15 \mathrm{~min}$.). Operating conditions for the mass spectrometer were $70 \mathrm{eV}$ and $230^{\circ} \mathrm{C}$ (ion source). Helium was used as carrier gas. Identification of $\mathrm{IP}_{25}$ is based on comparison of its retention time and mass spectra with published data [Belt et al., 2007]. The measurements were carried out using SIM (selected ion monitoring) mode (for further details see Müller et al. [2011] and Fahl and Stein [2012]). The Kovats index is 2085.

[20] Diatom analysis was carried out on discrete samples (approximately every $10 \mathrm{~cm}$ ) for NW-Pacific core SO201-2$12 \mathrm{KL}$. Observations by using a compound light-microscope were made at $1000 \times$ magnification. At least $300-500$ valves were counted per sample. The number of diatom valves per gram of sediments was estimated. Results are given as relative percentage of diatom species Fragilariopsis oceanica (Cleve) Hasle (F. oceanica) as sea-ice indicator, and Neodenticula seminae (Simonsen and Kanaya) Akiba and Yanagisawa ( $N$. seminae) related to open-water conditions.

\section{Results}

\subsection{Age Model}

[21] The color and XRF records have been used to correlate prominent and similar structures between sediment records. This approach also enabled a transfer of conventional ${ }^{14} \mathrm{C}$ ages from one core to another (Figure 2 and Table 2). We preferentially dated carbonate maxima (maxima in planktonic foraminifer abundance), which are indicated by maxima in $\mathrm{Ca}$ intensities (XRF), to avoid age artifacts due to bioturbation effects. Figure 2 shows the $\mathrm{Ca}$ intensity records and a detailed core-to-core correlation of our studied core sites. The pattern is marked by two intervals with high $\mathrm{Ca}$ intensities. These pronounced carbonate maxima are well known in the NW-Pacific realm and mark the $\mathrm{B} / \mathrm{A}$ and the interval of the early Holocene [Keigwin et al., 1992; Keigwin, 1998; Gorbarenko et al., 2002, 2005; Caissie et al., 2010]. The prominent carbonate maxima range from ca. $13,410(\mathrm{SO} 201-2-114 \mathrm{KL})$ to $11,950{ }^{14} \mathrm{C}$ years (SO201-2-85KL) and from ca. 10,800 (SO201-2-12KL) to $9,570{ }^{14} \mathrm{C}$ years $(\mathrm{SO} 201-2-77 \mathrm{KL})$. The structure of these carbonate maxima is best resolved in NW-Pacific sediment record SO201-2-12KL, which provides sedimentation rates of up to $80 \mathrm{~cm} / \mathrm{kyr}$ for these intervals. However, this record suggests that the maxima consist of a sequence of carbonate spikes that are not fully resolved in the other cores. At Shirshov Ridge, the interplay of lower sedimentation rates and bioturbation effects may have led to stratigraphic uncertainties in the early Holocene. In Shirshov cores SO201-2-77KL and SO201-2-85KL, the match between carbonate spikes 1 and 2 (Figure 2) and their corresponding ${ }^{14} \mathrm{C}$ ages provide an uncertainty of up to a few hundred years. In this case, we calculated and used an average ${ }^{14} \mathrm{C}$ age for each carbonate spike (spike $1=9,760{ }^{14} \mathrm{C}$ years; spike $2=10,383{ }^{14} \mathrm{C}$ years). At high-resolution core SO201-2-114KL from the northwestern continental margin of the Bering Sea, laminated sediment deposits characterize the intervals of both carbonate maxima (Figure 2).

[22] The mid to late Holocene time interval is marked by low carbonate contents in the NW-Pacific realm. Accordingly, the low abundance or complete absence of foraminifers prevented any planktonic ${ }^{14} \mathrm{C}$-dating of our records. However, for core LV29-114-3 from the Sea of Okhotsk, we improved the age control via correlation to the well-dated neighbor core V34-98 [Gorbarenko et al., 2002] and assigned one additional ${ }^{14} \mathrm{C}$ age to core LV29-114-3 (5,850 years) as shown in Figure 3.

[23] In addition, we also correlated the $\mathrm{Ca}$ intensity pattern of NW-Pacific core SO201-2-12KL and Sea of Okhotsk core LV29-114-3 to the pattern of NW-Pacific cores RAMA 44PC [Keigwin et al., 1992] and MD01-2416 [Sarnthein et al., 2004; Gebhardt et al., 2008]. This correlation provides a good match with the RAMA 44PC carbonate record. Sediment record MD01-2416 provides an excellent age model, including 15 planktonic ${ }^{14} \mathrm{C}$-datings, which covers the interval of the first pronounced carbonate maximum between $\mathrm{H} 1$ and the B/A. However, the carbonate maximum is less clearly developed in comparison to all other records presented here (Figure 2). A clear correlation is only possible by considering the ${ }^{14} \mathrm{C}$ ages. Furthermore, the $\mathrm{Ca}$ and $\mathrm{CaCO}_{3}$ structure at $9,985{ }^{14} \mathrm{C}$ years in core MD01-2416, which possibly marks the first $\mathrm{Ca}$-spike of the second carbonate maximum in the early Holocene, appears to be several hundred years too young in comparison to the age assignments of our Ca-records from the NW-Pacific, the Bering Sea and the Sea of Okhotsk (Figure 2). Consequently, we did not transfer any ${ }^{14} \mathrm{C}$ ages from core MD01-2416 to our records.

[24] In general, the sequence of ${ }^{14} \mathrm{C}$ data and their assignment to prominent carbonate structures is consistent between the investigated cores (within a range of a few hundred years) and can be traced from the Bering Sea to the NW-Pacific (except for core MD01-2416) and even into the Sea of Okhotsk. Hence, the registered temporal pattern of the carbonate maxima seems not to be significantly biased by water depth-dependent differences in carbonate dissolution at our investigated records, which range from 630 to $2200 \mathrm{~m}$ water depth. However, the ${ }^{14} \mathrm{C}$ ages of the carbonate maxima at our sediment records from the western Bering Sea (630 to $2200 \mathrm{~m}$ water depth) are about 200 years younger than in the NW-Pacific (2170 $\mathrm{m}$ water depth) and the Sea of Okhotsk (1765 m water depth). Since the Shirshov Ridge records cover the full range of water depth $(630$ to $2200 \mathrm{~m}$ ), we ascribe the temporal offset to regionally different ${ }^{14} \mathrm{C}$ surface ocean reservoir effects rather than to changes in carbonate dissolution. 


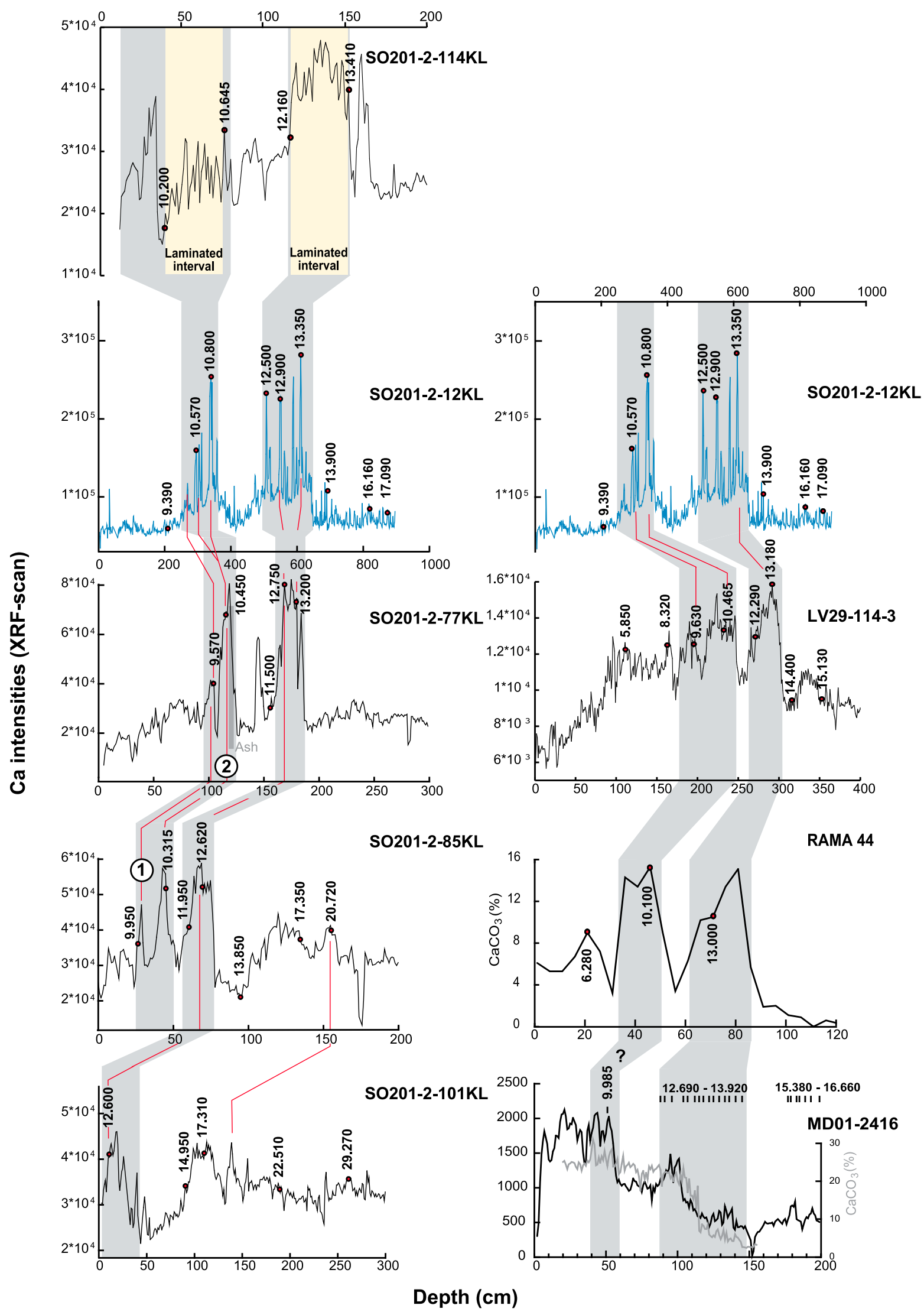

Figure 2 


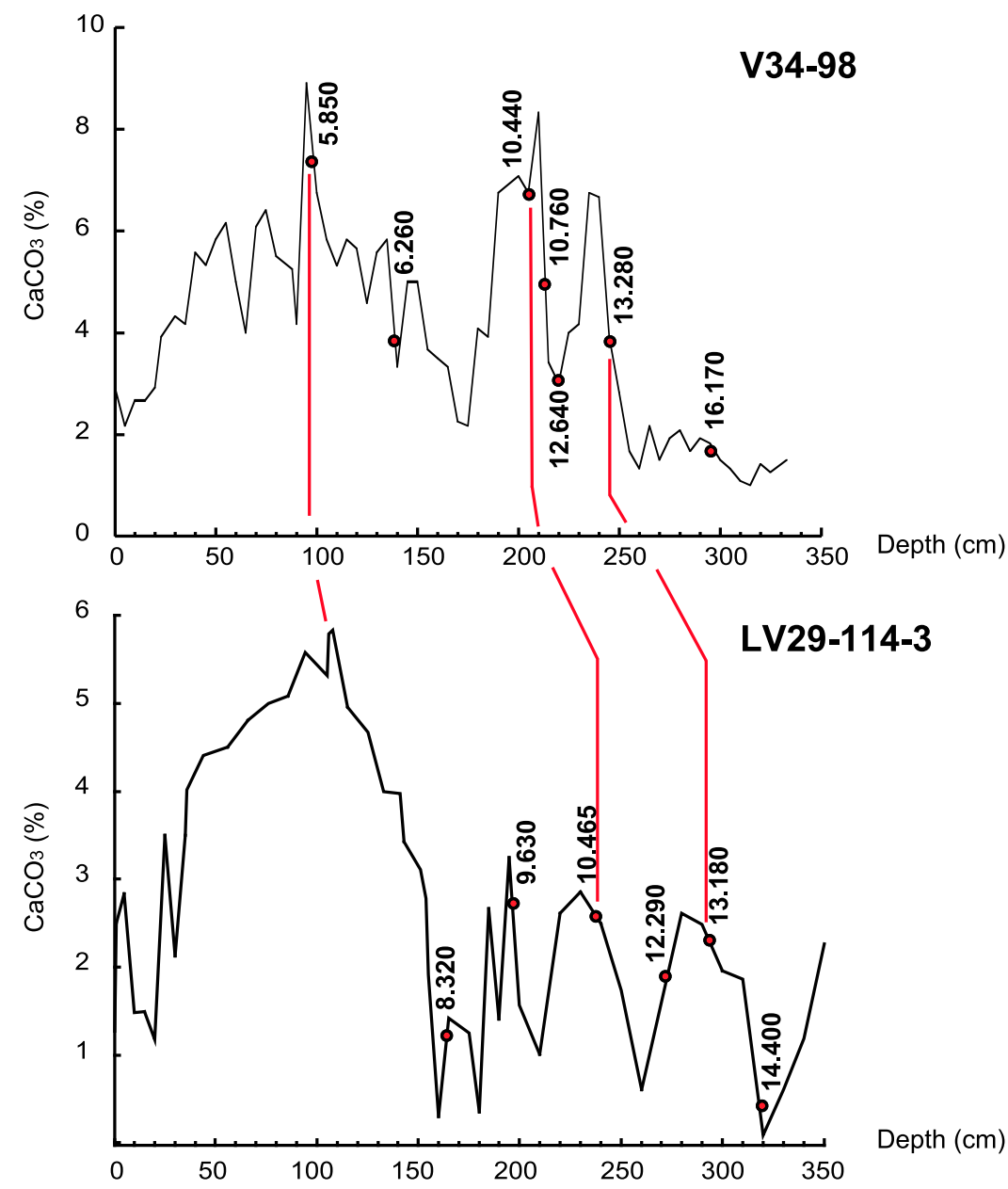

Figure 3. Correlation of sediment record LV29-114-3 with core V34-98 [Gorbarenko et al., 2002] based on $\mathrm{CaCO}_{3}(\%)$ data. Numbers with red spots indicate raw ${ }^{14} \mathrm{C}$ ages and red lines give correlation points. However, only the raw ${ }^{14} \mathrm{C}$ age of 5,850 years was transferred to sediment record LV29-114-3 to improve stratigraphic control in the upper part of this sediment core.

[25] The conversion of radiocarbon ages in calendar years requires a correction for the surface ocean reservoir age to balance out the ${ }^{14} \mathrm{C}$ effect of disequilibrium between the atmosphere and the upper ocean as well as the input of deep waters into the mixed layer. In the N-Pacific, the surface ocean reservoir age has been reported to range from 600 to 1,000 years [Southon et al., 1990; Kuzmin et al., 2001; McNeely et al., 2006; Yoneda et al., 2007]. There is increasing evidence that the reservoir age has also varied over the course of the last $20 \mathrm{kyr}$, which has been attributed to global thermohaline reorganizations as well as to changes in the upper-ocean stratification. For the N-Pacific, Sarnthein et al. [2006] and Gebhardt et al. [2008] suggest variable ${ }^{14} \mathrm{C}$ reservoir ages for the last $20 \mathrm{kyr}$, which have been derived by ${ }^{14} \mathrm{C}$-plateau tuning. For the ${ }^{14} \mathrm{C}$-plateaus at 12.3 kyr, 12.8-13.4 kyr and $14.9-15.3 \mathrm{kyr}$ (raw ${ }^{14} \mathrm{C}$ ages), reservoir ages of 450, 300 and 1150 years have been suggested [Sarnthein et al., 2007], respectively. In contrast, a more recent study claims that the surface ocean reservoir age was close to 730 years and varied by less than \pm 200 years during the last deglaciation in the NE-Pacific [Lund et al., 2011]. Since our ${ }^{14} \mathrm{C}$ datings are not dense enough to

Figure 2. (left) Stratigraphic framework of sediment records from the western Bering Sea and correlation with high-resolution record SO201-2-12KL record (blue curve) from the subarctic NW-Pacific. The stratigraphy is based on Ca intensity studies, derived from core logging data (XRF), together with raw AMS ${ }^{14} \mathrm{C}$ datings (red spots with vertical numbers). Grey shaded areas mark prominent carbonate maxima. Defined carbonate spikes (spike $1=9,760{ }^{14} \mathrm{C}$ years; spike $2=10,383{ }^{14} \mathrm{C}$ years) are numbered, and red lines indicate correlation points between the sediment records. (right) Comparison of Ca intensity data from high-resolution record SO201-2-12KL from the NW-Pacific (in blue) and LV29-114-3 from the Sea of Okhotsk to already published records from the open NW-Pacific (RAMA 44 [Keigwin, 1998] and MD01-2416 [Gebhardt et al., 2008]) $\mathrm{Ca}$ intensity and $\mathrm{CaCO}_{3}(\%)$ data. Red spots (vertical numbers) mark raw AMS ${ }^{14} \mathrm{C}$ datings, and grey shaded areas indicate carbonate maxima in the sediment records. Sediment record MD01-2416 provides best age control based on ${ }^{14} \mathrm{C}$-plateau tuning. However, no correlation was done to the records of this study due to discrepancies between the carbonate records of MD01-2416 and our sediment records. 
identify the age-calibrated ${ }^{14} \mathrm{C}$ - plateaus, we were not able to assess the variability of paleo-reservoir ages. Instead, we used constant reservoir ages over time with 700 years for the western Bering Sea cores and 900 years for the NW-Pacific and the Sea of Okhotsk records, which are within the range of NW-Pacific modern surface ocean reservoir ages. After converting the ${ }^{14} \mathrm{C}$ ages into calendar years, the difference in regional reservoir ages provides the best chronostratigraphic match between our high-resolution core-logging records (color $\mathrm{b}^{*}$ and $\mathrm{XRF}-\mathrm{Ca} / \mathrm{Ti}$ ratios). This assumes that the pattern of XRF-Ca/Ti ratios and color $b^{*}$ occurred synchronously in the NW-Pacific realm. Trends in color $b^{*}$ generally correlate with those of biogenic opal (Figure 4). Color $b^{*}$ is reported to provide a good proxy for variations in biogenic opal and total organic matter content of anoxic sediments [Debret et al., 2006]. The Sea of Okhotsk is marked by an increase in $\mathrm{CaCO}_{3}$ content rather than an increase of diatom production during the deglaciation [Seki et al., 2009]. Thus, we used the pattern of $\mathrm{Ca} / \mathrm{Ti}$ ratios in the Sea of Okhotsk record, which reflects changes in carbonate contents versus terrigenous siliciclastic input. Our age-depth control points within each record have been moved within the 1-sigma calendar age ranges to improve the fit between records. This also results in a good correlation to the Greenland temperature record (NGRIP) [Rasmussen et al., 2006] shown in Figure 4.

\subsection{SST Reconstructions}

[26] Calculated alkenone SSTs spanning the time period of the last $15 \mathrm{kyr}$ BP are shown in Figure 5. As expected, the SST records reflect successively increasing temperatures from north to south. At the southernmost site (core LV29114-3), the SSTs are about $3^{\circ} \mathrm{C}$ warmer than at the northernmost site (core SO201-2-114KL). A general feature of all records is the consistent temperature variability during the last glacial termination from $15 \mathrm{ka} \mathrm{BP}$ to $10 \mathrm{ka} \mathrm{BP}$. This temperature evolution is very similar to that reconstructed from Greenland ice core records, which mark the temperature rise from the end of $\mathrm{H} 1$ into the $\mathrm{B} / \mathrm{A}$, the subsequent cold spell of the YD and the following warming into the early Holocene (Figure 5). The early warming into the B/A does not capture the full amplitude of the SST increase, since all of our records are characterized by alkenone contents below the detection limit prior to $15 \mathrm{ka}$ BP. Hence, the amplitudes of the early temperature increase represent minimum ranges between 3 and $5^{\circ} \mathrm{C}$ at our studied sites, with lowest SSTs of $2-5.5^{\circ} \mathrm{C}$ at $15 \mathrm{ka} \mathrm{BP}$ and highest values ranging between 6 and $8^{\circ} \mathrm{C}$ during the $\mathrm{B} / \mathrm{A}$. The temperature decrease that followed into the YD is marked by amplitudes of $1.5-5^{\circ} \mathrm{C}$ with lowest amplitudes observed in Sea of Okhotsk core LV29-114-3. At each site, the subsequent temperature increase of up to $5^{\circ} \mathrm{C}$ consistently culminates in an early Holocene SST maximum between 11 and $9 \mathrm{ka} \mathrm{BP}$. All records display a maximum in SSTs of $9-10^{\circ} \mathrm{C}$ except for the northernmost core SO201-2-114KL from the Bering Sea, where the SST maximum remains approx. $3^{\circ} \mathrm{C}$ colder. The temperature development during the Holocene is only preserved in Bering Sea core SO201-2-77KL, northwest Pacific core SO201-2-12KL and Sea of Okhotsk core LV29114-3. These records point to a smooth and gradual SST decrease over the past 9 kyr. However, in Sea of Okhotsk core LV29-114-3, the temperature trend is interrupted by a cold spell between 9-7 ka BP. This pronounced SST minimum displays temperatures as cold as those found during the YD. Nevertheless, the SST trend in this record also suggests a gradual cooling in $\mathrm{SST}\left(3^{\circ} \mathrm{C}\right)$, which is best developed since $6 \mathrm{ka} \mathrm{BP}$. Another subtle difference can be observed for the time interval of the last $3.5 \mathrm{kyr}$. While the Bering Sea record suggests a slight warming, records from the NW Pacific and the Sea of Okhotsk indicate a further decline in SST.

\subsection{Sea-Ice Distribution}

[27] To assess past variations in sea-ice extent, we compared relative percentages of diatom species $F$. oceanica (indicative of sea-ice presence) and $N$. seminae (indicative of open water conditions) from sediment record SO201-2$12 \mathrm{KL}$ with qualitative measurements of the $\mathrm{IP}_{25}$ proxy (indicative of sea-ice presence), derived from specific time slices in all sediment records. The percentages of the diatom species (F. oceanica and $N$. seminae) point to millennial-scale variability in sea-ice presence, which is consistent with the SST development during the last $15 \mathrm{kyr}$ (Figure 6). Moderate amounts of $F$. oceanica mark the last glacial. Extremely low contents are typical for the B/A. Highest percentages characterize the YD and the subsequent warming phase at the end of termination 1. The SST maximum between approx. $10.5-9 \mathrm{ka} \mathrm{BP}$ is marked by the absence of $F$. oceanica. The last $9 \mathrm{kyr}$ are marked by a slight increase in $F$. oceanica. $N$. seminae provides an opposite trend between 15-10.5 ka $\mathrm{BP}$, suggesting open water conditions with reduced sea-ice presence during the $\mathrm{B} / \mathrm{A}$ and the Holocene SST maximum between 10.5-9 ka BP. Moderate contents of both $F$. oceanica and $N$. seminae are observed during the past $9 \mathrm{kyr}$ and may indicate temporal variations in sea-ice cover, allowing for both open water conditions as well as sea-ice presence.

[28] As mentioned above, we further applied the $\mathrm{IP}_{25}$ proxy, which is indicative of past variations in sea-ice extent. In all records (LV29-114-3, SO201-2-12KL, SO2012-77KL, SO201-2-85KL, SO201-2-101KL, SO201-2$114 \mathrm{KL})$ we measured $\mathrm{IP}_{25}$ at selected time slices (15.1 ka $\mathrm{BP}, 14.3 \mathrm{ka} \mathrm{BP}, 12.2 \mathrm{ka} \mathrm{BP}$ and $10.5 \mathrm{ka} \mathrm{BP})$, which are representative for distinct climate extremes $(\mathrm{H} 1, \mathrm{~B} / \mathrm{A}, \mathrm{YD}$, early Holocene SST maximum) recognized in our SST records (Figure 5). As shown for NW-Pacific core SO201-2$12 \mathrm{KL}$, by direct comparison between $F$. oceanica content and the occurrence of the $\mathrm{IP}_{25}$ biomarker, a consistent variability in sea-ice extend is documented and supports the applicability of the $\mathrm{IP}_{25}$ biomarker as sea-ice proxy in the subarctic NW-Pacific (Figure 6). The $\mathrm{IP}_{25}$ time slice reconstructions suggest that sea-ice was present during phases of $\mathrm{H} 1$ and the YD at each core location in the study area. Conversely, $\mathrm{IP}_{25}$ was not found in any sediment sample from samples covering the B/A and the early Holocene SST maximum. Accordingly, ice-free conditions mark the positions of all cores during these intervals.

\section{Discussion}

\subsection{Deglacial SST Development in the Subarctic NW-Pacific}

[29] The deglacial SST development in the subarctic NW-Pacific realm is reminiscent of the temporal evolution associated with millennial-scale climate variations revealed 

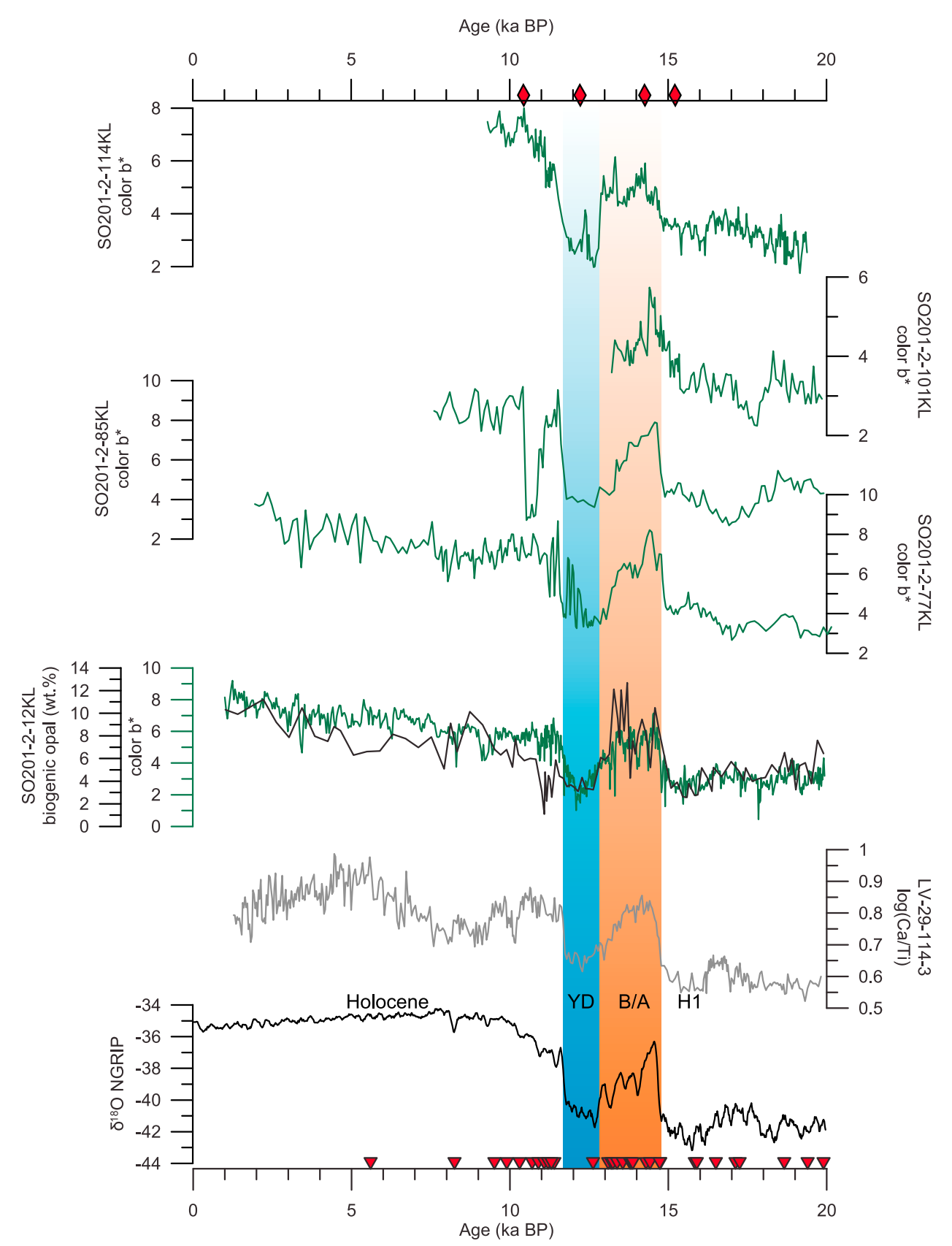

Figure 4. Spectrophotometric measurements (color $b^{*}$, green curves) from sediment records of the western Bering Sea, together with SO201-2-12KL from the NW-Pacific and $\log \mathrm{Ca} / \mathrm{Ti}$ ratio (XRF element intensities) of LV29-114-3 from the Sea of Okhotsk (in grey) against the NGRIP isotope record (in black) for the last $20 \mathrm{kyr}$ BP. Additionally, biogenic opal (\%) (thin black line) is given for SO201-2-12KL. Red triangles at the bottom mark ${ }^{14} \mathrm{C}$ age control points used in this study. Note the excellent correlation of all studied sediment records with the Greenland isotope record during the last $15 \mathrm{kyr}$ BP. Prominent climate stages as the B/A (shaded in red), the YD (shaded in blue) as well as the onset of the early Holocene are mimicked in the color $\mathrm{b}^{*}$ and $\log \mathrm{Ca} / \mathrm{Ti}$ proxy records. Red diamonds on top (representative of all sediment records) mark time slices used for the qualitative assessment of the $\mathrm{IP}_{25}$ sea-ice proxy. $\mathrm{IP}_{25}$ measurements were conducted on individual sediment records from samples according to the selected time slice.

by temperature records from Greenland and the N-Atlantic [e.g., Bard et al., 2000]. The alkenone temperature records obtained from the subarctic NW-Pacific, the Sea of Okhotsk and the Bering Sea suggest a deglacial warming, with a first warming at the onset of the B/A (14.7-12.9 ka BP), which was subsequently interrupted by a cooling phase associated with the YD cold phase (12.8-11.8 ka BP) and continued by a second and more pronounced warming into the early Holocene. Hence, this SST development matches the millennial-scale temperature fluctuations recognized in Greenland ice core records and N-Atlantic SST records and has also been reported in previous studies, which established 

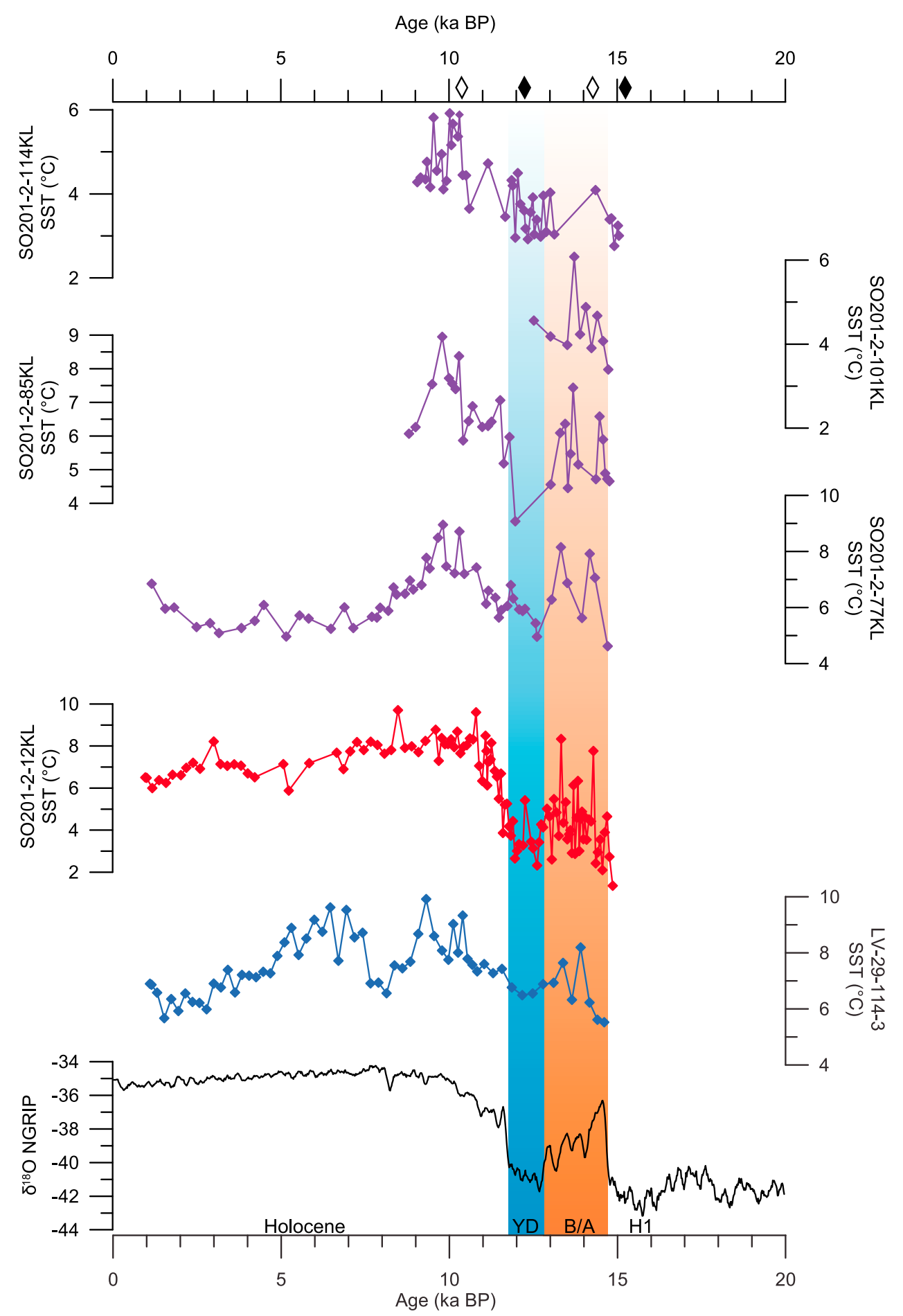

Figure 5. Results of the SST reconstructions from the western Bering Sea (in purple), the NW-Pacific (in red) and Sea of Okhotsk (blue curve) compared with the Greenland ice core record for the last $15 \mathrm{kyr}$ BP. Red shaded area marks the B/A and blue shaded bar indicate the YD cold spell in the records. Diamonds on top mark time slices used for the qualitative assessment of the $\mathrm{IP}_{25}$ sea-ice proxy (representative of all sediment records). Black diamonds on top mark time slices (H1 and YD), where the $\mathrm{IP}_{25}$ biomarker was found at all core sites and thus the presence of sea-ice inferred. In turn, white diamonds indicate time slices (B/A and early Holocene) where $\mathrm{IP}_{25}$ biomarker was absent at all core sites and no sea-ice cover inferred. 


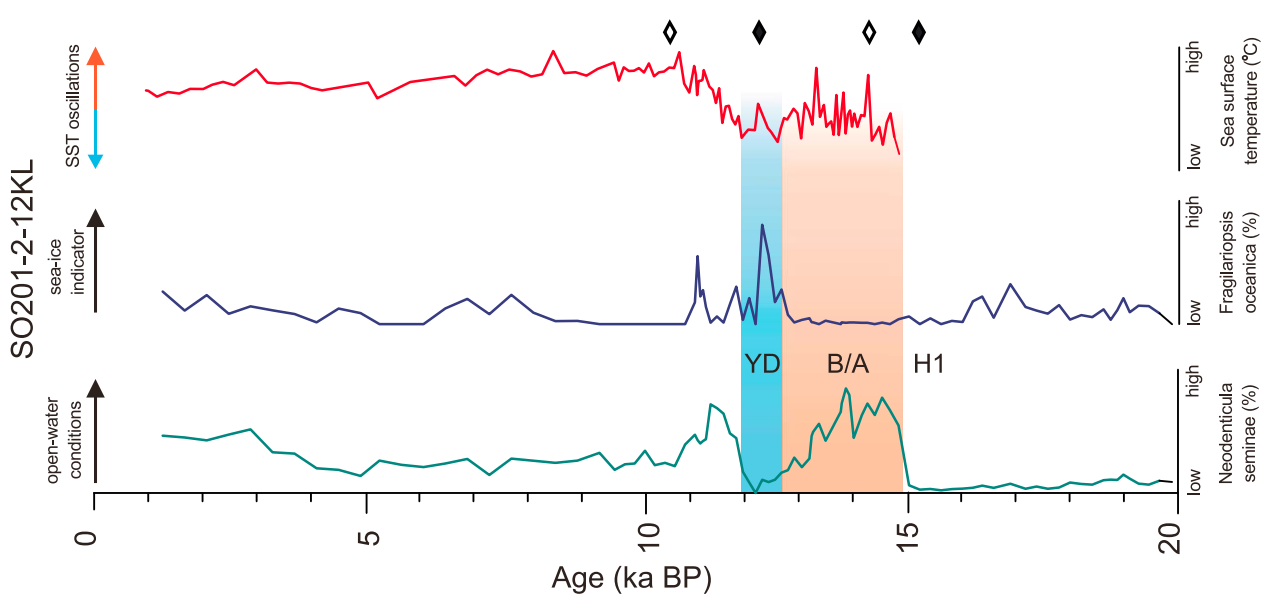

Figure 6. Results of the SST reconstructions from sediment record SO201-2-12KL (NW-Pacific) in red together with relative percentage of diatom Fragilariopsis oceanica (in blue) and Neodenticula seminae (in green). Red shaded area marks the B/A and blue shaded bar indicate the YD cold spell in the sediment records. Diamonds on top mark time slices used for the qualitative assessment of the $\mathrm{IP}_{25}$ sea-ice proxy (representative of all sediment records). Black diamonds on top mark time slices (H1 and YD), where the $\mathrm{IP}_{25}$ biomarker was found at all core sites and therefore the presence of sea-ice inferred. In turn, white diamonds indicate time slices $\left(\mathrm{B} / \mathrm{A}\right.$ and early Holocene) where no $\mathrm{IP}_{25}$ biomarker was found at all core sites and thus no sea-ice cover inferred.

alkenone-derived SST records from other parts of the NPacific realm as the NE-Pacific [Kienast and McKay, 2001; Barron et al., 2003], the eastern Bering Sea [Caissie et al., 2010], the Sea of Okhotsk [Ternois et al., 2000; Harada et al., 2006b; Seki et al., 2009; Harada et al., 2012] and off Japan [Harada et al., 2012]. On the basis of our age models, the deglacial SST variability in the NW-Pacific realm seems to be rather in-phase than out-of-phase with Greenland/N-Atlantic temperature changes (Figure 7). This would suggest a quasi-synchronicity between the N-Atlantic and N-Pacific SST development during the last glacial termination and argues for a strong atmospheric coupling between the N-Pacific and the N-Atlantic.

[30] The majority of model results also favors this interpretation and provides insights into the underlying mechanisms linking the development of SST between the $\mathrm{N}$-Atlantic and the N-Pacific. Numerous studies with coupled General Circulation Models (GCMs) have examined whether and how the millennial-scale climate oscillations in the N-Atlantic would impact the N-Pacific SST development via atmospheric and oceanic teleconnections during the last glacial termination. All models propose a close linkage to deglacial variations in AMOC. The temperature changes in the N-Atlantic region are closely coupled to a change in the strength of the AMOC, which is strongly modulated by freshwater forcing due to the instability of the Northern Hemisphere ice sheets and melting icebergs [Rahmstorf, 1995; McManus et al., 2004; Yin and Stouffer, 2007]. The freshwater input into the N-Atlantic led to a reduced thermohaline overturning, which also resulted in a reduced northward advection of saline and warm subtropical surface waters into the N-Atlantic [Manabe and Stouffer, 1988]. Manabe and Stouffer [1988] were among the first who demonstrated that the climatic impact of an AMOC shutdown is of global significance. Subsequent freshwater perturbation experiments also suggest, beyond the Atlantic basin, a robust response over the N-Pacific [e.g., Mikolajewicz et al., 1997; Vellinga and Wood, 2002; Okumura et al., 2009; Timmermann et al., 2010]. When the AMOC is substantially weakened (e.g., during H1 and the YD), N-Pacific summer and winter SSTs are suggested to have cooled by up to $3-6^{\circ} \mathrm{C}$. Most studies attribute the cooling to enhanced thermal advection of cold air masses from the N-Atlantic via westerly winds [Manabe and Stouffer, 1988]. As a result, the deepening of the Aleutian Low, the intensification in ocean-toatmosphere heat flux and southward Ekman transport in combination with the southward shift of the oceanic frontal system would have further cooled the N-Pacific. More recently, model experiments also provide hints for another atmospheric bridge between the N-Pacific and the subtropical Pacific/Atlantic that may have the potential to influence the strength of the Aleutian Low. Tropical SST anomalies in both the Atlantic and Pacific are found to be important for the barotropic response of the Aleutian Low [Okumura et al., 2009]. These mechanisms represent AMOC-induced fastacting atmospheric teleconnections on decadal timescales and suggest a similar temperature development between the $\mathrm{N}$-Atlantic and the N-Pacific.

[31] In contrast, Kiefer and Kienast [2005] and Gebhardt et al. [2008] found inversed millennial-scale SST oscillations with SST maxima at $\mathrm{H} 1$ and the YD in the NW-Pacific (core MD01-2416 and ODP883), as indicated by $\mathrm{Mg} / \mathrm{Ca}-$ derived and planktonic foraminiferal SIMMAX-based SSTs. This temporal NW-Pacific SST development is in harmony with model results from Huang et al. [2000] and Okazaki et al. [2010]. According to Huang et al. [2000], a slowdown of the Meridional Overturning Circulation in the $\mathrm{N}$ Atlantic (like during $\mathrm{H} 1$ and YD) may result in N-Pacific warming due to a reduction in upwelling of cold and nutrient-rich Pacific Deep Water in the N-Pacific subpolar gyre. However, the model experiments of Huang et al. [2000] do not consider the environmental background 


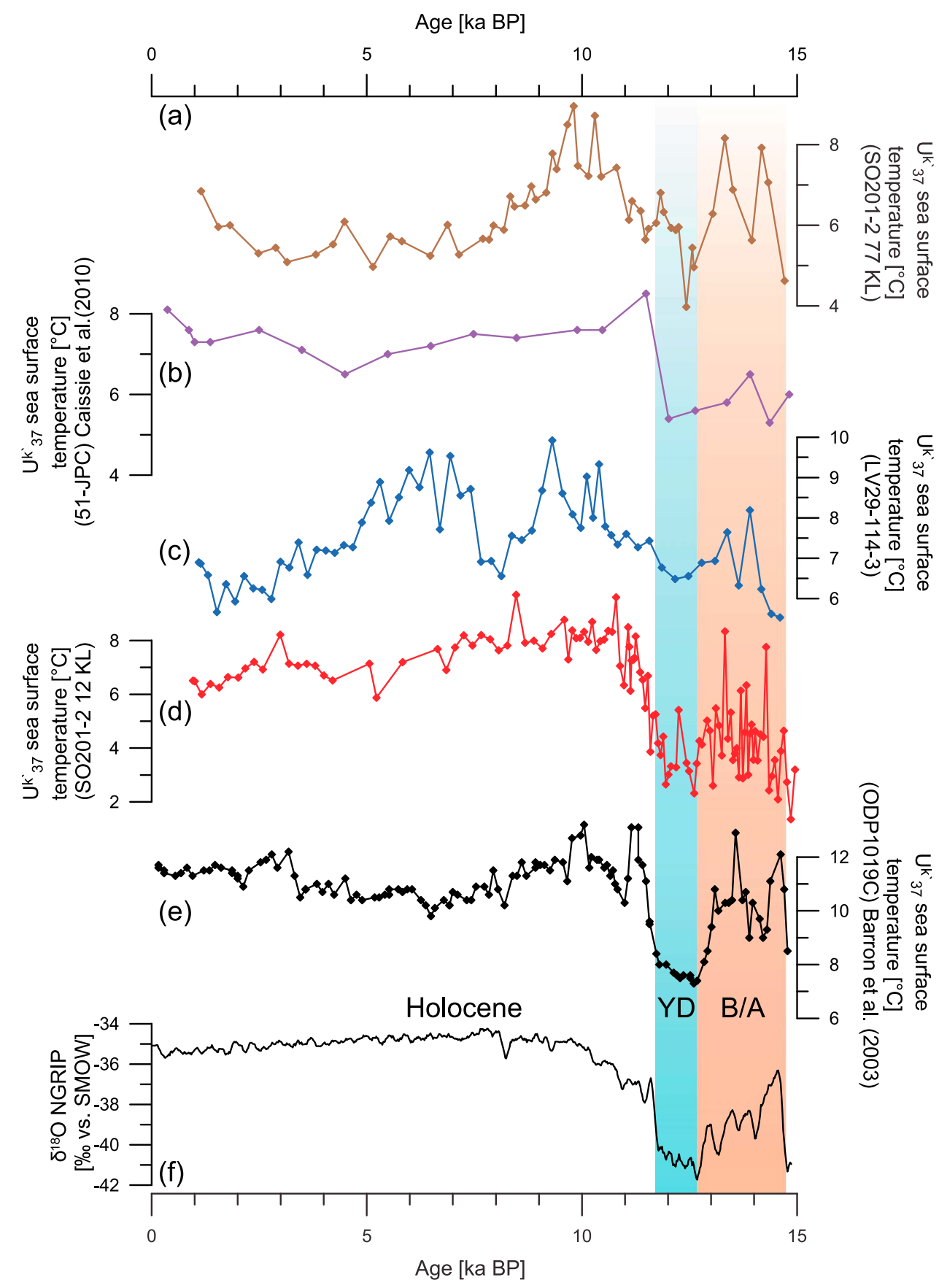

Figure 7. Alkenone-based SST reconstructions for the subarctic N-Pacific, including detailed comparison of (a) western Bering Sea, (b) eastern Bering Sea, (c) Sea of Okhotsk, (d) NW-Pacific, and (e) NE-Pacific compared with (f) NGRIP isotope record for the past 15 kyr. Red shaded area marks the $\mathrm{B} / \mathrm{A}$ and blue shaded bar indicates the YD cold spell in the records.

conditions associated with expanded Northern Hemisphere ice sheets during $\mathrm{H} 1$ and YD. The study of Okazaki et al. [2010] also suggests a warming in the N-Pacific during times of AMOC slowdown but due to the establishment of the PMOC. Thus, enhanced meridional overturning would result in strengthened northeastward upper-ocean heat transport via the North Pacific Current, thereby warming the N-Pacific, in particular in the Pacific Northeast. Recently, Chikamoto et al. [2012] simulated an AMOC shutdown using glacial boundary conditions (hereby considering a closed Bering Strait) and examined the impact on N-Pacific climate history by using two different models. Their results indicate that the spatial temperature pattern in the N-Pacific is strongly coupled to the strength of the PMOC. These model experiments suggest cooler SSTs in the subarctic NW-Pacific for both cases, a strong and a weak PMOC. However, in case of a strong PMOC, the NE-Pacific would experience surface warming due to an enhanced poleward transport of heat and salt from the subtropics to the extratropics via the Kuroshio-North Pacific 
Current system. Hence, the PMOC associated impact on SSTs seems to be too weak to compensate for the SST cooling in the NW-Pacific during times of expanded Northern Hemisphere ice sheets. These results favor AMOCinduced atmospheric teleconnections as the main driver for the SST development in the subarctic N-Pacific and are in accordance with our SST reconstructions from the NWPacific.

[32] However, the inconsistent deglacial trends between alkenone-derived SSTs (this study) and $\mathrm{Mg} / \mathrm{Ca}$-derived and planktonic foraminiferal SIMMAX-based SSTs [Kiefer and Kienast, 2005; Gebhardt et al., 2008] in the subarctic NPacific raise the question of whether the differences can be explained by stratigraphic uncertainties, in particular through the use of different SST proxies and/or are related to regional oceanographic deviations. The stratigraphic differences are mainly based on the application of different paleo-reservoir ${ }^{14} \mathrm{C}$ ages (chapter 4 ). Compared to our age model, their radiocarbon-based age constraints rely on variable reservoir ages [Sarnthein et al., 2006, 2007]. If we apply this variable reservoir correction to our age model (not shown), it would slightly and comparably affect the stratigraphic position of the $\mathrm{B} / \mathrm{A}$ temperature maximum in all our records. The temperature increase at the transition from the glacial into the $\mathrm{B} / \mathrm{A}$ would lead, relative to our age model, by 100-200 years. The end of this temperature maximum would lead that of our age model by up to 350 years. As a result, the temperature maximum would remain within the interval of the B/A and will not result in an anti-phased SST evolution between the $\mathrm{N}$-Pacific and the N-Atlantic in our records. Thus, the different appearance of the temperature maxima between our and other records (core MD01-2416, ODP-Site 883) cannot easily be ascribed to age model discrepancies. Assuming that the original planktonic ${ }^{14} \mathrm{C}$ ages (uncorrected) within the NW-Pacific region are marked by similar reservoir ages over time, the SST maxima and minima would occur at different time intervals in any case. For example, the most pronounced temperature maximum at core MD01-2416 occurs between $14,430-13,820{ }^{14} \mathrm{C}$ years (original) and has been assigned to the beginning of a ${ }^{14} \mathrm{C}$-plateau that ranges between 16,700-15,300 calendar years BP. The most pronounced temperature maximum in our SST records occurs between 13,350-12,500 ${ }^{14} \mathrm{C}$ years (original). These ages would correspond to another ${ }^{14} \mathrm{C}$-plateau, which marks the beginning of the B/A from 14,900-14,200 calendar years BP [Gebhardt et al., 2008]. However, core MD01-2416 provides no SST maximum at this stratigraphic position.

[33] Hence, we speculate that the different SST proxies are afflicted with diverse temperature signals due to seasonal bias and formation of the proxy signal at different water depths. The modern alkenone signal has been shown to reflect the late summer/autumn SST $(0-30 \mathrm{~m})$ in the NWPacific [Harada et al., 2003, 2006a; Seki et al., 2007]. The $\mathrm{Mg} / \mathrm{Ca}$-based temperatures are derived from the planktonic foraminifer $N$. pachyderma sin. and may reflect the winter signal due to its preferred habitat depth below or close to the thermocline [e.g., Bauch et al., 2002]. In particular, the modern water masses below the summer thermocline originate from intense and deep mixing during winter. Hence, a stronger temperature gradient between the depth habitat of the coccolithophorides and $N$. pachyderma sin. may result from enhanced stratification, intensified insolation and/or extra cooling of sub-thermocline waters in response to enhanced heat exchange with deeper and colder water masses [Kohfeld et al., 1996; Andersson et al., 2010]. Accordingly, such differences do not simply reflect changes in seasonality.

\subsection{Holocene SST Variability of the N-Pacific and its Marginal Seas}

[34] Alkenone-derived SST reconstructions from the NWPacific region are characterized by a pronounced temperature maximum during the early Holocene between 11 and 9 ka BP (Figures 5 and 8). This temperature maximum coincides with the maximum in Northern Hemisphere summer insolation (June-August) [Laskar et al., 2004]. In addition, recent model experiments suggest a reopening of the Bering Strait as another forcing mechanism [Okumura et al., 2009; Hu et al., 2010]. The reopening, which has been dated to approx. $11 \mathrm{ka}$ BP [e.g., Elias et al., 1997] may have led to increased meridional heat transport from the tropics to the extratropics and also warmed N-Pacific surface waters. The gateway-induced forcing may have been active for a restricted time interval, which may represent the phase of progressive marine inundation of the Bering Strait during rapid early Holocene sea level rise (11-8 ka BP) [Fleming et al., 1998]. Whether the N-Pacific SST maximum (11-9 ka BP) is affected by the opening of the Bering Strait remains elusive since the maximum also coincides with the maximum in Northern Hemisphere summer insolation.

[35] Our SST records in combination with existing SST records from the N-Pacific are further used to reassess the hypothesis of the long-term inverse temperature development between the N-Atlantic and N-Pacific from the middle to late Holocene [Kim et al., 2004]. According to Kim et al. [2004], SST trends have resembled a basin-scale, long-term $\mathrm{N}$-Pacific warming while the N-Atlantic has cooled during the last 7 kyr. However, the interpretation of Kim et al. [2004] is based on a single record from the subarctic NWPacific (GGC-15 [Ternois et al., 2000]), located in the Sea of Okhotsk. Our more comprehensive compilation of alkenonebased SST records from the N-Pacific and its marginal seas reveal no basin-scale, long-term warming trend over the past 7 kyr. The compilation of SST records from the N-Pacific realm hints to complex regional differences in the temperature development during the middle to late Holocene (Figure 8).

[36] In the Sea of Okhotsk, the middle to late Holocene SST development is characterized by different trends with relatively large temperature fluctuations (Figure 8). Core LV29-114-3 from the southeastern Sea of Okhotsk shows a clear cooling trend $\left(-3^{\circ} \mathrm{C}\right)$ during the last $7 \mathrm{kyr}$. In contrast, the neighbor core GGC-15, considered in the study of Kim et al. [2004], shows increased temperatures during this interval [Ternois et al., 2000]. However, this SST record is possibly biased by low alkenone contents in the middle to late Holocene interval [Ternois et al., 2000]. Three SST records from the central Sea of Okhotsk (XP98-PC 2 and -PC4, Seki et al., 2004a) and the southwestern Sea of Okhotsk (MD01-2412 [Harada et al., 2006b]) are marked by a pronounced temperature minimum between 6-3 ka BP. Only core MD01-2412 shows a clear SST trend, which points to a warming during the late Holocene (Figure 8). 


\section{Sea of Okhotsk}
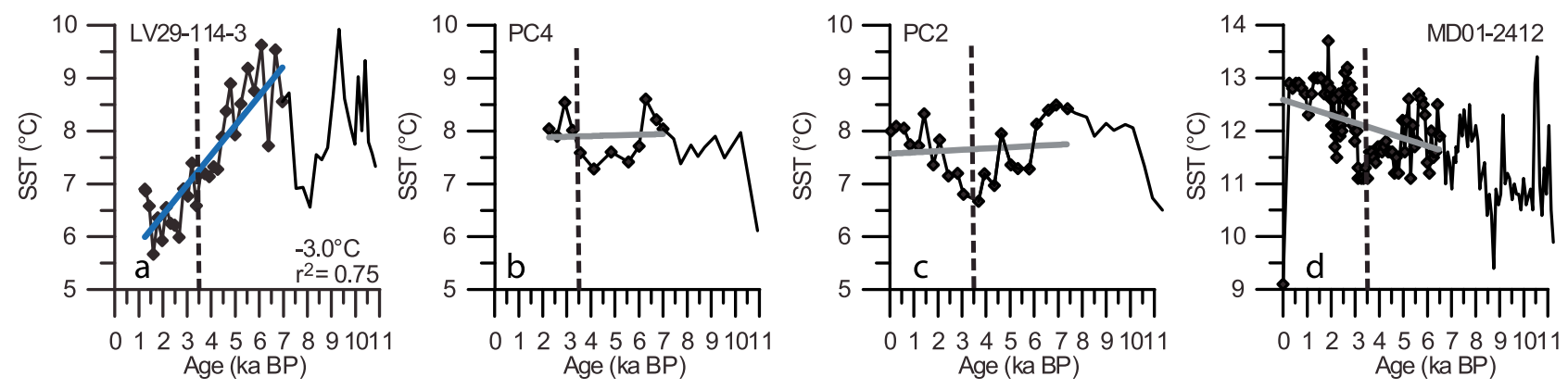

\section{Bering Sea}
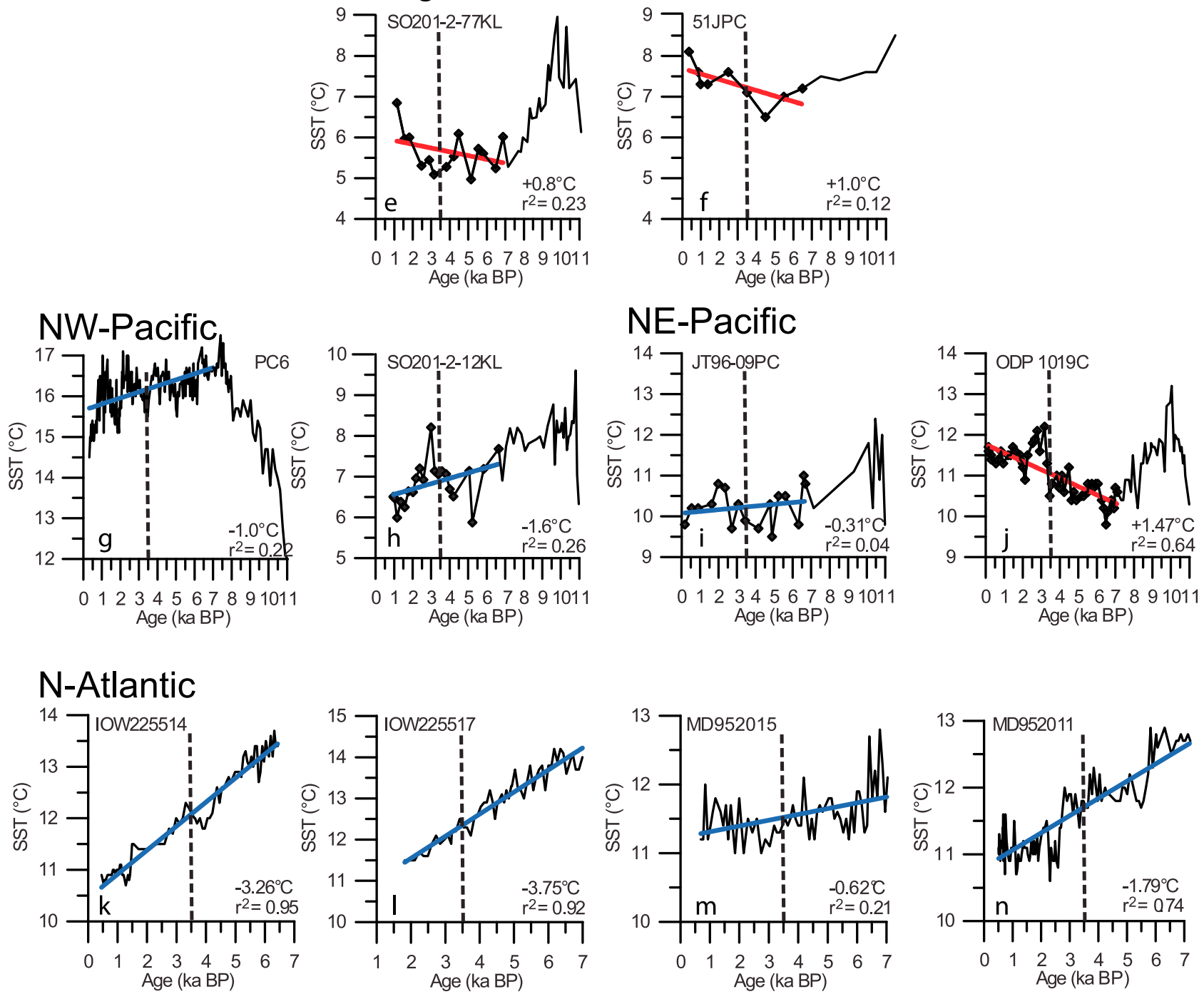

Figure 8. Holocene compilation of alkenone-based SST reconstructions for the (a-d) Sea of Okhotsk, (e and f) Bering Sea, (g and h) subarctic NW-Pacific, and (i and j) subarctic NE-Pacific compared with subarctic N-Atlantic alkenone-derived SSTs (k and 1) Emeis and Dawson [2003]; (m and n) Marchal et al. [2002]) from the middle to late Holocene. The stippled vertical lines indicate the middle to late Holocene boundary in every record. Linear regression trends are given for all records (blue, red and grey thick lines) for the last $7 \mathrm{kyr}$ BP. Correlation coefficients $\mathrm{r}^{2}$ are shown in the lower right corners, respectively. 

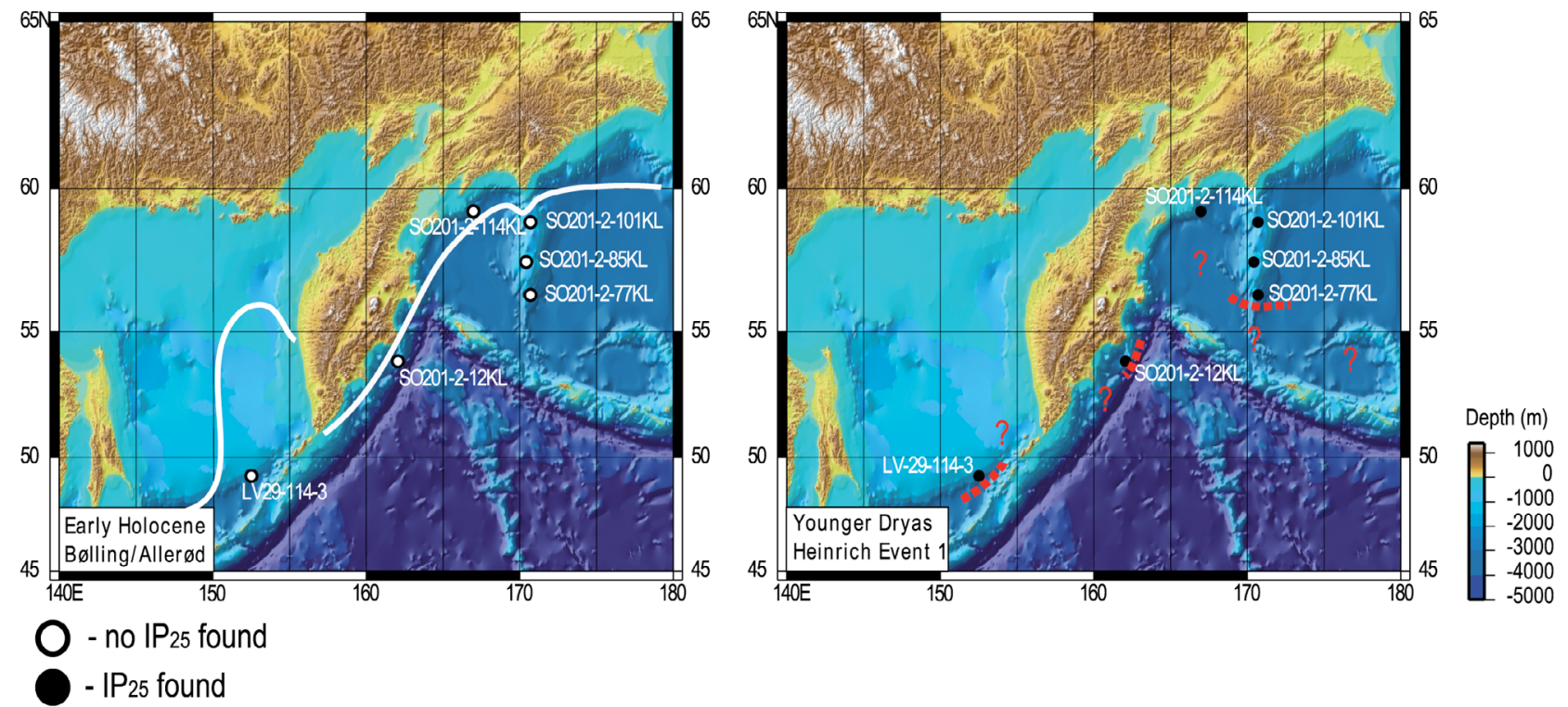

Figure 9. Sea-ice extent derived from occurrence/absence of $\mathrm{IP}_{25}$ sea-ice diatoms biomarker measured on a set of six sediment records during time slices of (left) the Bølling/Allerød and Early Holocene together with the modern sea-ice distribution (solid white line [Zhang et al., 2010]) and (right) the Younger Dryas and Heinrich Event 1 (dashed red lines) of the subarctic NW-Pacific. Question marks indicate regions where no information of the past sea-ice coverage is available. White circles indicate that no $\mathrm{IP}_{25}$ was found in the samples and black circles mark samples where $\mathrm{IP}_{25}$ was detected at the core site according to the time slice, respectively. Note the strong expansion of sea-ice in the subarctic NW-Pacific during times of $\mathrm{H} 1$ and $\mathrm{YD}$, where $\mathrm{IP}_{25}$ was detected at every core site and thus the sea-ice boundary was shifted several hundred miles to the South (especially in the western Bering Sea) compared to today. During phases of the $\mathrm{B} / \mathrm{A}$ and early Holocene, $\mathrm{IP}_{25}$ was absent in all sediment records and thus no sea-ice presence inferred at the core sites.

Altogether, we partly ascribe the differences in SST development to a variable inflow of surface water masses from the N-Pacific and the Japan Sea. Core LV29-114-3 is located at the main entrance of Pacific water masses delivered by the EKC (via Krusenstern Strait), which transports relatively cold water masses to the Sea of Okhotsk. Thus, the Holocene cooling trend at core LV29-114-3 might be related to temperature changes in the source region of the EKC. On the other hand, core MD01-2412 is influenced by the inflow of warm water masses from the Japan Sea via the Soya Strait. The warming trend may indicate a strengthened influence of the Japan Sea.

[37] In the Bering Sea, the middle to late Holocene SST development is derived from two sediment records (HLY0202-51JPC [Caissie et al., 2010]; SO201-2-77KL, this study). Both temperature records reveal a consistent SST development with a net warming indicated by the linear regression trend (Figure 8). This trend seems to be related to a SST rise around the mid- to late Holocene transition (ca. $3.5 \mathrm{ka} \mathrm{BP}$ ).

[38] The subarctic NW-Pacific SST records reveal a cooling trend from the middle to late Holocene (PC6 [Minoshima et al., 2007]; SO201-2-12KL (this study); Figure 8). Available temperature records from the subarctic NE-Pacific margin show no consistent picture of SST development during the last 7 kyr (JT96-09PC [Kienast and McKay, 2001]; ODP 1019C [Barron et al., 2003]; Figure 8). As the SST record from core JT96-09PC indicates weak cooling over the last $7 \mathrm{kyr}$, SSTs at ODP site 1019 are marked by a clear warming trend.

[39] In summary, the compilation of alkenone-derived SST records from the N-Pacific and its marginal seas show no consistent SST trends and thus do not corroborate the basin-scale, long-term warming from the middle to late Holocene in the N-Pacific [Kim et al., 2004]. Regionally consistent trends in SST development are observed for the Bering Sea and the subarctic NW-Pacific, however, with opposing trends during the last 7 kyr. The Bering Sea is marked by a warming trend and the subarctic NW-Pacific is characterized by a cooling trend from the middle to late Holocene. The SST development within the Sea of Okhotsk is rather diverse. The cooling trend in the NW-Pacific could be partly attributed to the decrease in summer insolation. On the other hand, the opposing SST development in the Bering Sea as well as the diverse SST trends in the Sea of Okhotsk also call for a strong imprint of other processes (internal forcing), involving atmosphere-ocean interactions. AMOCinduced changes, which apparently played a key role for the deglacial SST development in the subarctic N-Pacific, seem to be of minor importance since the thermohaline circulation has been reported to be relatively stable during the middle to late Holocene [e.g., McManus et al., 2004].

\subsection{Changes in Sea-Ice Extent}

[40] The variability in sea-ice distribution during the last glacial termination is closely coupled to the general SST 
development in the subarctic Pacific realm, although the alkenone-derived SSTs most likely reflect summer-autumn temperature variations and are not associated with the seasonal maximum in sea-ice extent. The qualitative assessment of sea-ice extent $\left(\mathrm{IP}_{25}\right)$ in the subarctic NW-Pacific suggests a highly dynamic sea-ice cover (Figure 9), which oscillated at least over several hundred miles during the last deglaciation. In the study area, the advancement of sea-ice reached all core sites during cold phases of $\mathrm{H} 1$ and the $\mathrm{YD}$ and was accompanied by coldest temperatures as derived from our SST records (Figure 5). The common occurrence of $\mathrm{IP}_{25}$ in the sediments clearly points to vast expansion of sea-ice in a generally colder climate during $\mathrm{H} 1$ and YD in the subarctic NW-Pacific. However, due to the limited spatial coverage of sediment cores, the maximum expansion in seasonal sea-ice cover may have been much larger during these intervals. Conversely, the absence of $\mathrm{IP}_{25}$ suggests ice-free conditions at all our core locations during phases of the B/A and the early Holocene warm intervals, which also matches warmest intervals derived from our SST records (Figure 5). During the early Holocene, the maximum in sea-ice extent was even more limited compared to today [Zhang et al., 2010] (Figure 9). This is suggested by the absence of $\mathrm{IP}_{25}$ at the northernmost core site SO201-2-114KL, which today is influenced by seaice advances during winter. These findings are underpinned by pronounced millennial-scale shifts in diatom assemblages at core SO201-2-12KL, indicative for changes in seasonal sea-ice cover during the past $15 \mathrm{kyr}$ (Figure 6). High percentages of $F$. oceanica suggest the presence of sea-ice during the YD. High percentages of $N$. seminae reflect open water conditions during the $\mathrm{B} / \mathrm{A}$ and the early Holocene. Combining the information of both proxies $\left(\mathrm{IP}_{25}\right.$ and diatom assemblages) also enables us to identify different stages of sea-ice conditions, e.g., permanent sea-ice coverage versus seasonal or no sea-ice presence. With respect to the position of core SO201-2-12KL, high amounts of $F$. oceanica during the YD and relatively low amounts during the last glacial do not necessarily represent a discrepancy. Since $N$. seminae is marked by extremely low values during both intervals, we infer that the glacial position of the sea-ice margin was further offshore of core SO201-2-12KL, compared to the YD. At the core site, perennial sea-ice cover prevailed during the glacial, and the retreat of the summer sea-ice boundary may have reached the core location only occasionally. This interpretation is also supported by low total diatom abundance during the last glacial. The low diatom abundance is probably a result of enhanced sea-ice coverage, which further limits phytoplankton growth. After $\sim 15 \mathrm{ka} \mathrm{BP}$ (beginning of the $\mathrm{B} / \mathrm{A}$ ), total diatom abundance is higher by an order of magnitude (not shown). In general, our results are in harmony with previous sea-ice reconstructions based on diatom assemblages and paleo-productivity studies in the subarctic Pacific realm [Sancetta, 1983; Sancetta and Robinson, 1983; Sancetta, 1992; Cook et al., 2005; Katsuki and Takahashi, 2005; Okazaki et al., 2005; Sakamoto et al., 2006; Katsuki et al., 2009; Caissie et al., 2010]. The conclusive variability between SST and the $\mathrm{IP}_{25}$-proxy highlights the potential of this relatively new sea-ice proxy as tool for more detailed spatial time slice reconstructions in the N-Pacific realm in order to further assess the climate dynamics and feedback mechanisms during millennial-scale climate fluctuations of the last deglaciation.

\section{Conclusions}

[41] Our conclusions can be summarized into four main points.

[42] 1. Alkenone-temperatures derived from high-resolution sediment records in the subarctic NW-Pacific, the Sea of Okhotsk and the western Bering Sea show a deglacial temperature evolution similar to the NE-Pacific and even to the $\mathrm{N}$-Atlantic and Greenland temperature variability. From this we suggest a close linkage to deglacial variations in AMOC associated with rapid atmospheric teleconnections, which resulted in a quasi-synchronous SST development between the N-Atlantic and the N-Pacific during the last glacial termination. Although the SST variability between the $\mathrm{N}$ Atlantic and N-Pacific show striking temporal similarities, uncertainties in age control related to a lack of knowledge in ${ }^{14} \mathrm{C}$ reservoir ages may bias the timing of SST changes by up to several hundred years.

[43] 2. During the middle to late Holocene, the subarctic N-Pacific reveals complex SST trends, suggesting strong regional overprints. The compilation of alkenone-derived SST records from the NW-Pacific, the Bering Sea and the Sea of Okhotsk does not support the hypothesis of a longterm Holocene temperature seesaw between the N-Atlantic and N-Pacific associated with a basin-scale warming trend in the N-Pacific during the last 7 kyr. Only the Bering Sea records reveal a tendency toward warmer temperatures compared to a slight cooling in the NW-Pacific. The records from the Sea of Okhotsk exhibit both cooling and warming trends as well as large fluctuations during the middle to late Holocene.

[44] 3. Past sea-ice expansion were reconstructed from a set of six sediment records by qualitative assessment of the $\mathrm{IP}_{25}$ biomarker for cold (H1 and YD) and warm (B/A and early Holocene) stages and compared to diatom studies during the last glacial termination in the NW-Pacific. Our results suggest a strong variability of sea-ice extent and a close coupling to SST fluctuations in the N-Pacific. The seaice advanced at least by several hundred miles during phases of $\mathrm{H} 1$ and YD. During the phases of B/A and the early Holocene the maximum in sea-ice cover seems to have been even more reduced compared to today.

[45] 4. Our SST records in combination with the sea-ice reconstructions provide no evidence of surface warming during the YD and H1, which has been suggested by several climate models to occur in response of enhanced deep water formation in the N-Pacific.

[46] Acknowledgments. This study resulted from the GermanRussian multidisciplinary research project "KALMAR-Kurile-Kamchatka and Aleutean Marginal Sea-Island Arc Systems: Geodynamic and Climate Interaction in Space and Time." We gratefully acknowledge the Master and crew of R/V Sonne cruise SO201-2 and thank them for their professional support onboard. Lukas Belz and Adelina Manurung are thanked for technical assistance in the geochemical laboratory. We also would like to thank the three anonymous reviewers, who helped to improve the quality of this manuscript. This study was funded by the German Federal Ministry of Education and Research (BMBF) grant 03G0672B and 03G0672A. 


\section{References}

Andersson, C., F. S. R. Pausata, E. Jansen, B. Risebrobakken, and R. J. Telford (2010), Holocene trends in the foraminifer record from the Norwegian Sea and the North Atlantic Ocean, Clim. Past, 6(2), 179-193, doi:10.5194/cp-6-179-2010.

Bard, E., F. Rostek, J. L. Turon, and S. Gendreau (2000), Hydrological impact of Heinrich events in the subtropical northeast Atlantic, Science, 289(5483), 1321-1324, doi:10.1126/science.289.5483.1321.

Barron, J. A., L. Heusser, T. Herbert, and M. Lyle (2003), High-resolution climatic evolution of coastal northern California during the past 16,000 years, Paleoceanography, 18(1), 1020, doi:10.1029/2002PA000768.

Bauch, D., H. Erlenkeuser, G. Winckler, G. Pavlova, and J. Thiede (2002), Carbon isotopes and habitat of polar planktic foraminifera in the Okhotsk Sea The 'carbonate ion effect' under natural conditions, Mar. Micropaleontol., 45(2), 83-99, doi:10.1016/S0377-8398(02)00038-5.

Belt, S. T., G. Masse, S. J. Rowland, M. Poulin, C. Michel, and B. LeBlanc (2007), A novel chemical fossil of palaeo sea ice: IP25, Org. Geochem. 38(1), 16-27, doi:10.1016/j.orggeochem.2006.09.013.

Brassell, S. C., G. Eglinton, I. T. Marlowe, U. Pflaumann, and M. Sarnthein (1986), Molecular stratigraphy: A new tool for climatic assessment, Nature, 320(6058), 129-133, doi:10.1038/320129a0.

Caissie, B. E., J. Brigham-Grette, K. T. Lawrence, T. D. Herbert, and M. S. Cook (2010), Last Glacial Maximum to Holocene sea surface conditions at Umnak Plateau, Bering Sea, as inferred from diatom, alkenone, and stable isotope records, Paleoceanography, 25, PA1206, doi:10.1029/ 2008PA001671.

Chikamoto, M. O., L. Menviel, A. Abe-Ouchi, R. Ohgaito, A. Timmermann, Y. Okazaki, N. Harada, A. Oka, and A. Mouchet (2012), Variability in North Pacific intermediate and deep water ventialtion during Heinrich events in two coupled climate models, Deep Sea Res., Part II, 61-64, 114-126, doi:10.1016/j.dsr2.2011.12.002.

Cook, M. S., L. D. Keigwin, and C. A. Sancetta (2005), The deglacial history of surface and intermediate water of the Bering Sea, Deep Sea Res., Part II, 52(16-18), 2163-2173, doi:10.1016/j.dsr2.2005.07.004.

Debret, M., M. Desmet, W. Balsam, Y. Copard, P. Francus, and C. La (2006), Spectrophotometer analysis of Holocene sediments from an anoxic fjord: Saanich Inlet, British Columbia, Canada, Mar. Geol., 229(1-2), 15-28, doi:10.1016/j.margeo.2006.01.005.

DeMaster, D. J. (1981), The supply and accumulation of silica in the marine environment, Geochim. Cosmochim. Acta, 45(10), 1715-1732, doi:10.1016/0016-7037(81)90006-5.

Dullo, W.-C., B. Baranov, and C. van den Bogaard (Eds.) (2009), FS Sonne Fahrtbericht/Cruise Report SO201-2, IFM-GEOMAR Rep. 35, 233 pp. IFM-GEOMAR, Kiel, Germany.

Elias, S. A., S. K. Short, and H. H. Birks (1997), Late Wisconsin environments of the Bering Land Bridge, Palaeogeogr. Palaeoclimatol. Palaeoecol., 136(1-4), 293-308, doi:10.1016/S0031-0182(97)00038-2.

Emeis, K. C., and A. G. Dawson (2003), Holocene palaeoclimate records over Europe and the North Atlantic, Holocene, 13(3), 305-309, doi:10.1191/0959683603hl622ed.

Fahl, K., and R. Stein (2012), Modern seasonal variability and deglacial/ Holocene change of central Arctic Ocean sea-ice cover: New insights from biomarker proxy records, Earth Planet. Sci. Lett., in press.

Fleming, K., P. Johnston, D. Zwartz, Y. Yokoyama, K. Lambeck, and J. Chappell (1998), Refining the eustatic sea-level curve since the Last Glacial Maximum using far- and intermediate-field sites, Earth Planet. Sci. Lett., 163(1-4), 327-342, doi:10.1016/S0012-821X(98)00198-8.

Gebhardt, H., M. Sarnthein, P. M. Grootes, T. Kiefer, H. Kuehn, F. Schmieder and U. Rohl (2008), Paleonutrient and productivity records from the subarctic North Pacific for Pleistocene glacial terminations I to V, Paleoceanography, 23, PA4212, doi:10.1029/2007PA001513.

Gorbarenko, S. A., T. A. Khusid, I. A. Basov, T. Oba, J. R. Southon, and I. Koizumi (2002), Glacial Holocene environment of the southeastern Okhotsk Sea: Evidence from geochemical and palaeontological data Palaeogeogr. Palaeoclimatol. Palaeoecol., 177(3-4), 237-263, doi:10.1016/ S0031-0182(01)00335-2.

Gorbarenko, S. A., I. A. Basov, M. P. Chekhovskaya, J. Southon, T. A. Khusid, and A. Artemova (2005), Orbital and millennium scale environmental changes in the southern Bering Sea during the last glacial-Holocene: Geochemical and paleontological evidence, Deep Sea Res., Part II, 52(16-18), 2174-2185, doi:10.1016/j.dsr2.2005.08.005.

Harada, N., K. H. Shin, A. Murata, M. Uchida, and T. Nakatani (2003) Characteristics of alkenones synthesized by a bloom of Emiliania huxleyi in the Bering Sea, Geochim. Cosmochim. Acta, 67(8), 1507-1519, doi:10.1016/S0016-7037(02)01318-2.

Harada, N., M. Sato, A. Shiraishi, and M. C. Honda (2006a), Characteristics of alkenone distributions in suspended and sinking particles in the northwestern North Pacific, Geochim. Cosmochim. Acta, 70(8), 20452062, doi:10.1016/j.gca.2006.01.024.

Harada, N., N. Ahagon, T. Sakamoto, M. Uchida, M. Ikehara, and Y. Shibata (2006b), Rapid fluctuation of alkenone temperature in the southwestern Okhotsk Sea during the past $120 \mathrm{ky}$, Global Planet. Change, 53(1-2), 29-46, doi:10.1016/j.gloplacha.2006.01.010.

Harada, N., et al. (2012), Sea Surface temperature changes in the Okhotsk Sea and adjacent North Pacific during the last glacial maximum and deglaciation, Deep Sea Res., Part II, 61-64, 93-105, doi:10.1016/j.dsr2.2011.12.007.

Honda, M. C., K. Imai, Y. Nojiri, F. Hoshi, T. Sugawara, and M. Kusakabe (2002), The biological pump in the northwestern North Pacific based on fluxes and major components of particulate matter obtained by sediment-trap experiments (1997-2000), Deep Sea Res., Part II, 49(24-25), 5595-5625, doi:10.1016/S0967-0645(02)00201-1.

Hu, A. X., G. A. Meehl, B. L. Otto-Bliesner, C. Waelbroeck, W. Q. Han, M. F. Loutre, K. Lambeck, J. X. Mitrovica, and N. Rosenbloom (2010), Influence of Bering Strait flow and North Atlantic circulation on glacial sea-level changes, Nat. Geosci., 3(2), 118-121, doi:10.1038/ngeo729.

Huang, R. X., M. A. Cane, N. Naik, and P. Goodman (2000), Global adjustment of the thermocline in response to deepwater formation, Geophys. Res. Lett., 27(6), 759-762, doi:10.1029/1999GL002365.

Katsuki, K., and K. Takahashi (2005), Diatoms as paleoenvironmental proxies for seasonal productivity, sea-ice and surface circulation in the Bering Sea during the late Quaternary, Deep Sea Res., Part II, 52(16-18), 2110-2130, doi:10.1016/j.dsr2.2005.07.001.

Katsuki, K., B. K. Khim, T. Itaki, N. Harada, H. Sakai, T. Ikeda, K. Takahashi, Y. Okazaki, and H. Asahi (2009), Land-sea linkage of Holocene paleoclimate on the Southern Bering Continental Shelf, Holocene, 19(5), 747-756, doi:10.1177/0959683609105298.

Keigwin, L. D. (1998), Glacial-age hydrography of the far northwest Pacific Ocean, Paleoceanography, 13(4), 323-339, doi:10.1029/98PA00874.

Keigwin, L. D., G. A. Jones, and P. N. Froelich (1992), A 15,000 year paleoenvironmental record from Meiji Seamount, far northwestern Pacific, Earth Planet. Sci. Lett., 111(2-4), 425-440, doi:10.1016/0012821X(92)90194-Z.

Kiefer, T., and M. Kienast (2005), Patterns of deglacial warming in the Pacific Ocean: A review with emphasis on the time interval of Heinrich event 1, Quat. Sci. Rev., 24(7-9), 1063-1081, doi:10.1016/j.quascirev.2004.02.021. Kiefer, T., M. Sarnthein, H. Erlenkeuser, P. M. Grootes, and A. P. Roberts (2001), North Pacific response to millennial-scale changes in ocean circulation over the last $60 \mathrm{kyr}$, Paleoceanography, 16(2), 179-189, doi:10.1029/2000PA000545.

Kienast, S. S., and J. L. McKay (2001), Sea surface temperatures in the subarctic Northeast Pacific reflect millennial-scale climate oscillations during the last 16 kyrs, Geophys. Res. Lett., 28(8), 1563-1566, doi:10.1029/2000GL012543.

Kim, J. H., N. Rimbu, S. J. Lorenz, G. Lohmann, S. I. Nam, S. Schouten, C. Ruhlemann, and R. R. Schneider (2004), North Pacific and North Atlantic sea-surface temperature variability during the holocene, Quat. Sci. Rev., 23(20-22), 2141-2154, doi:10.1016/j.quascirev.2004.08.010.

Kohfeld, K. E., R. G. Fairbanks, S. L. Smith, and I. D. Walsh (1996) Neogloboquadrina pachyderma (sinistral coiling) as paleoceanographic tracers in polar oceans: Evidence from northeast water Polynya plankton tows, sediment traps, and surface sediments, Paleoceanography, 11(6), 679-699, doi:10.1029/96PA02617.

Kuzmin, Y. V., G. S. Burr, and A. J. T. Jull (2001), Radiocarbon reservoir correction ages in the Peter the Great Gulf, Sea of Japan, and eastern coast of the Kunashir, southern Kuriles (northwestern Pacific), Radiocarbon, 43(2A), 477-481.

Laskar, J., P. Robutel, F. Joutel, M. Gastineau, A. C. M. Correia, and B. Levrard (2004), A long-term numerical solution for the insolation quantities of the Earth, Astron. Astrophys., 428(1), 261-285, doi:10.1051/0004-6361:20041335.

Lund, D. C., A. C. Mix, and J. Southon (2011), Increased ventilation age of the deep northeast Pacific Ocean during the last deglaciation, Nat. Geosci., 4(11), 771-774, doi:10.1038/ngeo1272.

Manabe, S., and R. J. Stouffer (1988), Two stable equilibria of a coupled ocean-atmosphere model, J. Clim., 1, 841-866, doi:10.1175/1520 0442(1988)001<0841:TSEOAC $>2.0$. CO;2.

Mantua, N. J., S. R. Hare, Y. Zhang, J. M. Wallace, and R. C. Francis (1997), A Pacific interdecadal climate oscillation with impacts on salmon production, Bull. Am. Meteorol. Soc., 78(6), 1069-1079, doi:10.1175/ 1520-0477(1997)078<1069:APICOW >2.0.CO 2

Marchal, O., et al. (2002), Apparent long-term cooling of the sea surface in the northeast Atlantic and Mediterranean during the Holocene, Quat. Sci. Rev., 21(4-6), 455-483, doi:10.1016/S0277-3791(01)00105-6. 
McManus, J. F., R. Francois, J. M. Gherardi, L. D. Keigwin, and S. BrownLeger (2004), Collapse and rapid resumption of Atlantic meridional circulation linked to deglacial climate changes, Nature, 428(6985), 834-837, doi:10.1038/nature02494.

McNeely, R., A. S. Dyke, and J. R. Southon (2006), Canadian marine reservoir ages, preliminary data assessment, Geol. Surv. Can.Open File Rep. 5049, 3 pp., Geol. Surv. of Can., Ottawa.

Mikolajewicz, U., T. J. Crowley, A. Schiller, and R. Voss (1997), Modelling teleconnections between the North Atlantic and North Pacific during the Younger Dryas, Nature, 387(6631), 384-387, doi:10.1038/387384a0

Minoshima, K., H. Kawahata, and K. Ikehara (2007), Changes in biologica production in the mixed water region (MWR) of the northwestern North Pacific during the last $27 \mathrm{kyr}$, Palaeogeogr. Palaeoclimatol. Palaeoecol., 254(3-4), 430-447, doi:10.1016/j.palaeo.2007.06.022.

Müller, P. J., and R. Schneider (1993), An automated leaching method for the determination of opal in sediments and particulate matter, Deep Sea Res., Part I, 40(3), 425-444, doi:10.1016/0967-0637(93)90140-X.

Müller, P. J., G. Kirst, G. Ruhland, I. von Storch, and A. Rosell-Mele (1998), Calibration of the alkenone paleotemperature index $\mathrm{U}_{37}^{\mathrm{K}^{\prime}}$ based on core-tops from the eastern South Atlantic and the global ocean $\left(60^{\circ} \mathrm{N}-60^{\circ} \mathrm{S}\right), \quad$ Geochim. Cosmochim. Acta, 62(10), 1757-1772, doi:10.1016/S0016-7037(98)00097-0.

Müller, J., G. Masse, R. Stein, and S. T. Belt (2009), Variability of sea-ice conditions in the Fram Strait over the past 30,000 years, Nat. Geosci. 2(11), 772-776, doi:10.1038/ngeo665.

Müller, J., A. Wagner, K. Fahl, R. Stein, M. Prange, and G. Lohmann (2011), Towards quantitative sea ice reconstructions in the northern North Atlantic: A combined biomarker and numerical modelling approach, Earth Planet. Sci. Lett., 306(3-4), 137-148, doi:10.1016/j.eps1.2011.04.011.

Niebauer, H. J. (1988), Effect of El Nino Southern Oscillation and North Pacific weather patterns on interannual variability in the subarctic Bering Sea, J. Geophys. Res., 93(C5), 5051-5068, doi:10.1029/JC093iC05p05051.

Niebauer, H. J. (1998), Variability in Bering Sea ice cover as affected by a regime shift in the North Pacific in the period 1947-1996, J. Geophys. Res., 103(C12), 27,717-27,737, doi:10.1029/98JC02499.

Ohtani, K., Y. Akiba, and A. Y. Takenouti (1972), Formation of western subarctic water in the Bering Sea, in Biological Oceanography of the Northern North Pacific Ocean, edited by A. Y. Takenouti, pp. 32-44, Idemitsu Shoten, Tokyo.

Okazaki, Y., K. Takahashi, K. Katsuki, A. Ono, J. Hori, T. Sakamoto, M. Uchida, Y. Shibata, M. Ikehara, and K. Aoki (2005), Late Quaternary paleoceanographic changes in the southwestern Okhotsk Sea: Evidence from geochemical, radiolarian, and diatom records, Deep Sea Res., Part II, 52(16-18), 2332-2350, doi:10.1016/j.dsr2.2005.07.007.

Okazaki, Y., A. Timmermann, L. Menviel, N. Harada, A. Abe-Ouchi, M. O. Chikamoto, A. Mouchet, and H. Asahi (2010), Deepwater formation in the North Pacific during the Last Glacial Termination, Science, 329(5988), 200-204, doi:10.1126/science.1190612.

Okumura, Y. M., C. Deser, A. Hu, A. Timmermann, and S. P. Xie (2009), North Pacific climate response to freshwater forcing in the subarctic North Atlantic: Oceanic and atmospheric pathways, J. Clim., 22(6), 1424-1445, doi:10.1175/2008JCLI2511.1.

Overland, J. E., N. A. Bond, and J. M. Adams (2002), The relation of surface forcing of the Bering Sea to large-scale climate patterns, Deep Sea Res., Part II, 49(26), 5855-5868, doi:10.1016/S0967-0645(02)00322-3.

Pisias, N. G., A. C. Mix, and L. Heusser (2001), Millennial scale climate variability of the northeast Pacific Ocean and northwest North America based on radiolaria and pollen, Quat. Sci. Rev., 20(14), 1561-1576, doi:10.1016/S0277-3791(01)00018-X.

Prahl, F. G., and S. G. Wakeham (1987), Calibration of unsaturation patterns in long-chain ketone compositions for paleotemperature assessment, Nature, 330(6146), 367-369, doi:10.1038/330367a0.

Rahmstorf, S. (1995), Bifurcations of the atlantic thermohaline circulation in response to changes in the hydrological cycle, Nature, 378(6553), 145-149, doi:10.1038/378145a0.

Rasmussen, S. O., et al. (2006), A new Greenland ice core chronology for the last glacial termination, J. Geophys. Res., 111, D06102, doi:10.1029/2005JD006079.

Reimer, P. J., et al. (2009), Intcal09 and Marine09 radiocarbon age calibration curves, 0-50,000 years cal BP, Radiocarbon, 51(4), 1111-1150.

Saenko, O. A., A. Schmittner, and A. J. Weaver (2004), The Atlantic-Pacific seesaw, J. Clim., 17(11), 2033-2038, doi:10.1175/15200442(2004)017<2033:TAS>2.0.CO;2.

Sakamoto, T., et al. (2006), Millennial-scale variations of sea-ice expansion in the southwestern part of the Okhotsk Sea during the past $120 \mathrm{kyr}$ : Age model and ice-rafted debris in IMAGES Core MD01-2412, Global Planet. Change, 53(1-2), 58-77, doi:10.1016/j.gloplacha.2006.01.012.
Sancetta, C. (1983), Effect of Pleistocene glaciation upon oceanographic characteristics of the North Pacific Ocean and Bering Sea, Deep Sea Res., Part A, 30(8), 851-869, doi:10.1016/0198-0149(83)90004-3.

Sancetta, C. (1992), Primary production in the glacial North Atlantic and North Pacific oceans, Nature, 360(6401), 249-251, doi:10.1038/ $360249 \mathrm{a} 0$.

Sancetta, C., and S. W. Robinson (1983), Diatom evidence on Wisconsin and Holocene events in the Bering Sea, Quat. Res., 20(2), 232-245, doi:10.1016/0033-5894(83)90079-0.

Sarnthein, M., H. Gebhardt, T. Kiefer, M. Kucera, M. Cook, and H. Erlenkeuser (2004), Mid Holocene origin of the sea-surface salinity low in the subarctic North Pacific, Quat. Sci. Rev., 23(20-22), 2089-2099, doi:10.1016/j.quascirev.2004.08.008

Sarnthein, M., T. Kiefer, P. M. Grootes, H. Elderfield, and H. Erlenkeuser (2006), Warmings in the far northwestern Pacific promoted pre-Clovis immigration to America during Heinrich event 1, Geology, 34(3), 141-144, doi:10.1130/G22200.1.

Sarnthein, M., P. M. Grootes, J. P. Kennett, and M.-J. Nadeau (2007), ${ }^{14} \mathrm{C}$ reservoir ages show deglacial changes in ocean currents and carbon cycle, in Ocean Circulation: Mechanisms and Impacts-Past and Future Changes of Meridional Overturning, Geophys. Monogr. Ser., vol. 173 , edited by A. Schmittner, J. C. H. Chiang, and S. R. Hemming, pp. 175-196, AGU, Washington, D. C., doi:10.1029/173GM13

Schmittner, A., E. D. Galbraith, S. W. Hostetler, T. F. Pedersen, and R. Zhang (2007), Large fluctuations of dissolved oxygen in the Indian and Pacific oceans during Dansgaard-Oeschger oscillations caused by variations of North Atlantic Deep Water subduction, Paleoceanography, 22, PA3207, doi:10.1029/2006PA001384.

Seki, O., R. Ishiwatari, and K. Matsumoto (2002), Millennial climate oscillations in NE Pacific surface waters, Geophys. Res. Lett., 29(23), 2144 doi:10.1029/2002GL015200

Seki, O., K. Kawamura, M. Ikehara, T. Nakatsuka, and T. Oba (2004a), Variation of alkenone sea surface temperature in the Sea of Okhotsk over the last 85 kyrs, Org. Geochem., 35(3), 347-354, doi:10.1016/j.orggeochem.2003.10.011

Seki, O., M. Ikehara, K. Kawamura, T. Nakatsuka, K. Ohnishi, M. Wakatsuchi, H. Narita, and T. Sakamoto (2004b), Reconstruction of paleoproductivity in the Sea of Okhotsk over the last $30 \mathrm{kyr}$, Paleoceanography, 19, PA1016, doi:10.1029/2002PA000808.

Seki, O., T. Nakatsuka, K. Kawamura, S. I. Saitoh, and M. Wakatsuchi (2007), Time-series sediment trap record of alkenones from the western Sea of Okhotsk, Mar. Chem., 104(3-4), 253-265, doi:10.1016/j.marchem.2006.12.002.

Seki, O., T. Sakamoto, S. Sakai, S. Schouten, E. C. Hopmans, J. S. Sinninghe Damste, and R. D. Pancost (2009), Large changes in seasonal sea ice distribution and productivity in the Sea of Okhotsk during the deglaciations, Geochem. Geophys. Geosyst., 10, Q10007, doi:10.1029/ 2009GC002613.

Sikes, E. L., J. K. Volkman, L. G. Robertson, and J. J. Pichon (1997), Alkenones and alkenes in surface waters and sediments of the Southern Ocean: Implications for paleotemperature estimation in polar regions, Geochim. Cosmochim. Acta, 61(7), 1495-1505, doi:10.1016/S00167037(97)00017-3

Southon, J. R., D. E. Nelson, and J. S. Vogel (1990), A record of past ocean-atmosphere radiocarbon differences from the Northeast Pacific, Paleoceanography, 5(2), 197-206, doi:10.1029/PA005i002p00197.

Stabeno, P. J., J. D. Schumacher, and K. Ohtani (1999), The physical oceanography of the Bering Sea, in Dynamics of the Bering Sea, edited by T. R. Loughlin and K. Ohtani, pp. 1-28, Univ. of Alaska Sea Grant, Fairbanks.

Stuiver, M. (1980), Workshop on C-14 Data Reporting, Radiocarbon, 22(3), 964-966.

Stuiver, M., and H. A. Polach (1977), Reporting of C-14 Data - Discussion, Radiocarbon, 19(3), 355-363.

Stuiver, M., and P. J. Reimer (1993), Extended C-14 Data-Base and Revised Calib 3.0 C-14 Age Calibration Program, Radiocarbon, 35(1), 215-230.

Ternois, Y., K. Kawamura, N. Ohkouchi, and L. Keigwin (2000), Alkenone sea surface temperature in the Okhotsk Sea for the last $15 \mathrm{kyr}$, Geochem. $J ., 34(4), 283-293$, doi:10.2343/geochemj.34.283.

Timmermann, A., L. Menviel, Y. Okumura, A. Schilla, U. Merkel, O. Timm, A. X. Hu, B. Otto-Bliesner, and M. Schulz (2010), Towards a quantitative understanding of millennial-scale Antarctic warming events, Quat. Sci. Rev., 29(1-2), 74-85.

Vellinga, M., and R. A. Wood (2002), Global climatic impacts of a collapse of the Atlantic thermohaline circulation, Clim. Change, 54(3), 251-267, doi:10.1023/A:1016168827653.

Yin, J. J., and R. J. Stouffer (2007), Comparison of the stability of the Atlantic thermohaline circulation in two coupled atmosphere-ocean 
general circulation models, J. Clim., 20(17), 4293-4315, doi:10.1175/ JCLI4256.1.

Yoneda, M., H. Uno, Y. Shibata, R. Suzuki, Y. Kumamoto, K. Yoshida, T. Sasaki, A. Suzuki, and H. Kawahata (2007), Radiocarbon marine reservoir ages in the western Pacific estimated by pre-bomb molluscan shells, Nucl. Instrum. Methods Phys. Res., Sect. B, 259(1), 432-437, doi:10.1016/j.nimb.2007.01.184.

Zhang, J. L., R. Woodgate, and R. Moritz (2010), Sea ice response to atmospheric and oceanic forcing in the Bering Sea, J. Phys. Oceanogr., 40(8), 1729-1747, doi:10.1175/2010JPO4323.1. 